\title{
"Black economic empowerment in post-1994 South Africa: ANC curse and/or socialist/communist covenant?"
}

\begin{tabular}{|c|c|c|}
\hline AUTHORS & \multicolumn{2}{|c|}{ Louis P. Krüger (D https://orcid.org/0000-0003-3632-427X } \\
\hline ARTICLE INFO & \multicolumn{2}{|c|}{$\begin{array}{l}\text { Louis P. Krüger (2016). Black economic empowerment in post-1994 South Africa: } \\
\text { ANC curse and/or socialist/communist covenant?. Problems and Perspectives in } \\
\text { Management, 14(3-1), 162-178. doi:10.21511/ppm.14(3-1).2016.03 }\end{array}$} \\
\hline DOI & \multicolumn{2}{|c|}{ http://dx.doi.org/10.21511/ppm.14(3-1).2016.03 } \\
\hline RELEASED ON & \multicolumn{2}{|l|}{ Tuesday, 06 September 2016} \\
\hline JOURNAL & \multicolumn{2}{|c|}{ "Problems and Perspectives in Management" } \\
\hline FOUNDER & \multicolumn{2}{|c|}{ LLC "Consulting Publishing Company "Business Perspectives" } \\
\hline & & ニ=: \\
\hline NUMBER OF REFERENCES & NUMBER OF FIGURES & NUMBER OF TABLES \\
\hline
\end{tabular}

(c) The author(s) 2022. This publication is an open access article. 
Louis P. Krüger (South Africa)

\title{
Black economic empowerment in post-1994 South Africa: ANC curse and/or socialist/communist covenant?
}

\begin{abstract}
After more than 21 years under the leadership of the African National Congress (ANC), post-1994 South Africa finds itself yet again embroiled in race-related politics. Government policies such as black economic empowerment (BEE) and employment equity (EE) have not brought about the economic growth, social development and political democracy that the late former President Nelson Mandela had envisaged and what the ANC had promised to all the people of South Africa. South Africa is currently disengaging itself from the West including the Unites States of America (USA) and certain European Union (EU) countries and appears to rather embrace and align itself with countries such as Russia and China that pursue socialist and communist ideologies. Both these two issues may have a profound impact on how businesses will be managed in the future. In an exploratory, qualitative study using a " 5 Star" research methodology, the direct and indirect impacts of BEE policies were investigated and the possible movement in South Africa's ideological stance was explored. BEE does not appear to have helped to bring about high economic growth to help to reduce unemployment and eradicate the high levels of poverty and inequality, and government graft and corruption have increased at all levels of government, including local municipalities. BEE appears to have become the ANC's curse to economic, social and political progress and should be scrapped. A national debate should follow on whether the ANC's current covenant with pro-socialism and procommunism rather than Western free-market capitalism is the appropriate ideology for South Africa to pursue.
\end{abstract}

Keywords: black economic empowerment (BEE), employment equity (EE), African National Congress (ANC), capitalism, socialism, communism.

JEL Classification: M14, M21.

\section{Introduction}

Dr Anthea Jeffery, a respected political analyst who is the head of the policy research unit at the South African Institute for Race Relations (IRR), in a recent (3 September 2015) online article wrote the following: "The ruling African National Congress (ANC) seems intent on alienating the West and adopting a rigid proRussia and pro-China stance. However, the Western countries it is busy targeting have long been South Africa's most important investors, whereas investment from China and Russia has, thus, far been very limited". She, then, provides the financial figures for foreign direct investment (FDI) and non-direct foreign investment in South Africa, which is overwhelmingly dominated by Western countries (but excludes Canada and Australia, along with Japan and Taiwan) (85\% or R1 350 bn of a total of R1 600 bn) and (90\% or R2 435 bn of a total of R2 695 bn), respectively. In contrast, FDI by China is paltry at R59 bn or 3.5\% of the total, with Russia's FDI being even less. Similarly, non-direct investment of China is R14.5 bn or $0.95 \%$ of the total, while that of Russia is again negligible. Dr Jeffery goes on to caution the ruling party, the ANC, that it "cannot afford to put anti-Western ideology before the urgent needs of the economy. Nor should it assume that China and Russia - both of which are themselves in increasing economic difficulties - will be able make up for the Western investment now being put at risk" (Jeffery, 2015a).

\section{(C) Louis P. Krüger, 2016}

Louis P. Krüger, BSc (QS), MBA, DBA (UP) University of Pretoria, Professor in Operations, Project and Quality Management, Department of Business Management at the University of South Africa, South Africa.
Black economic empowerment (BEE) is but one of the many initiatives and pieces of legislation that the ANC has implemented in South Africa post-1994 in an effort to improve the lives of the majority, eradicate poverty and address unemployment of citizens who for many years were excluded on account of apartheid policies. It is also probably one of the more controversial measures taken, because, firstly, it is based on the empowerment of a particular race, and, secondly, it represents a fundamental shift and alignment with the socialist and communist ideologies of Russia and China, away from the Western and European, free-market capitalist systems, which have been the prominent and enduring economic systems since the founding of the Republic of South Africa in $1961^{1}$.

The present level of corruption in South Africa has been acknowledged by the ruling party as " ... a cancer that has no place in the ANC nor South African society ..." (SAPA, 2014a) and is considered "... a cancer to development ... which is hampering economic integration .... and Africa's social and economic development ". BEE, which is unfortunately and predominantly associated with many cases of corruption, fraud, nepotism, favoritism, and the socalled "tenderpreneurs" with their BEE procurement practices, has either been hailed or feared in South

\footnotetext{
${ }^{1}$ The Union of South Africa was formed on 31 May 1910 and became a sovereign independent state from Great Britain in 1934. Twenty-six years later, South Africa withdrew from the Commonwealth and became the independent Republic of South Africa on 31 May 1961 (Anonymous, 2014). After these early years, under the influence of the British political and economic systems, South Africa adopted a Western style (capitalist-driven) free-market economy.
} 
Africa and as "[h]elping or [h]urting?" (Jeffery, 2014) or being "a curse or some form of a covenant?" (Author's note written on 13 November 2014).

This article reports the findings of an exploratory qualitative research study which adopted a "5 Star" research methodology (developed by the author in 2014) to investigate this apparent dichotomy, of whether BEE is "good" or "bad" for the country and if it is putting the country on a path which is more aligned with the social, economic and political outcomes found in most socialist and communist ideological states.

\section{Background to the research}

The researcher has been involved with BEE research specifically for more than five years and has thus far published five journal articles on this topic. In the fourth article, he attempted to assess South African managers' perceptions and conceptions (or misconceptions) relating to the practical implementation prescripts, compliance measures and so forth of BEE (Krüger, 2014a). In the last article, to complete the circle, having covered the essence of what BEE is, which people or businesses are affected, how they are affected, and where BEE has its impact, it was appropriate to lastly consider in an article (Krüger, 2014b), why BEE in business is justified at all.

BEE or its extended version referred to as broadbased black economic empowerment (B-BBEE) in South Africa is legislated under Act 53 of 2003 and was introduced during the first term of the second post-1994 elected president, former president Thabo Mbeki. The B-BBEE Act provides the legislative framework for the promotion of B-BBEE and empowers the Minister (of Trade and Industry) and the Department of Trade and Industry to administer all the provisions of the Act in order to advance economic transformation and enhance the economic participation of black people in the South African economy (DTI, 2016a).

The objectives of B-BBEE, according to the Act, are to "... promote the achievement of the constitutional right to equality, increase broad-based and effective participation of black people in the economy and promote a higher growth rate, increased employment and more equitable income distribution; and establish a national policy on broad-based black economic empowerment so as to promote the economic unity of the nation, protect the common market, and promote equal opportunity and equal access to government services ...".

Officially, according to the B-BBEE Amendment Act 46 of 2013, 'black people' is a generic term which means Africans, Coloureds and Indians:

1. who are citizens of the Republic of South Africa by birth or descent;
2. who became citizens of the Republic of South Africa by naturalization:

2.1. before 27 April 1994; or

2.2. on or after 27 April 1994 and who would have been entitled to acquire citizenship by naturalization prior to that date; and 'broad-based black economic empowerment' means the viable economic empowerment of all black people [including], in particular, women, workers, youth, people with disabilities and people living in rural areas through diverse, but integrated socioeconomic strategies that include, but not limited to:

- increasing the number of black people that manage, own and control;

- enterprises and productive assets;

- facilitating ownership and management of enterprises and productive;

- assets by communities, workers, cooperatives and other collective enterprises;

- human resource and skills development;

- achieving equitable representation in all occupational categories and levels in the workforce;

- preferential procurement from enterprises that are owned or managed by black people; and

- investment in enterprises that are owned or managed by "black people".

For the purposes of this research, certain "working definitions" were accepted when referring to the ideologies of capitalism, socialism and communism. Working definitions refer to a general definition or understanding of the term(s) used in the context of this research. They are as follows:

- Free-market economy - "A market economy based on supply and demand with little or no government control. "A free-market economy is a market-based economy where prices for goods and services are set freely by the forces of supply and demand and are allowed to reach their point of equilibrium without intervention by government policy, and it typically entails support for highly competitive markets and private ownership of productive enterprises. ... free markets are commonly associated with capitalism in contemporary usage and popular culture ...".

- Capitalism - "A system of economics based on the private ownership of capital and production inputs, and on the production of goods and services for profit. The production of goods and services is based on supply and demand in the general market (market economy), rather than through central planning (planned economy)". "Capitalism is an economic system in which trade, industry, and the means of production are largely or entirely privately owned and operated for profit. 
Central characteristics of capitalism include capital accumulation, competitive markets and wage labor".

- Command economy - "A system where the government, rather than the free market, determines what goods should be produced, how much should be produced and the price at which the goods will be offered for sale". "A command economy is when government makes decisions, or a planned economy, is an economic system where the main economic decisions (such as allocating scarce resources like labor, capital, soil and natural resources) are taken by a central body; which is usually the government".

- Socialism - "An economic and political system based on public or collective ownership of the means of production". "Socialism is a social and economic system characterized by social ownership of the means of production and cooperative management of the economy, as well as a political theory".

- Communism - "A political and economic ideology based on communal ownership and the absence of class". "Communism is a socioeconomic system structured upon common ownership of the means of production and characterized by the absence of social classes, money, and the state, as well as a social, political and economic ideology and movement that aims to establish this social order".

\section{Research methodology}

The research on which this article is based falls within the interpretivist/constructivist paradigm (or theoretical framework). Such an approach in research attempts "... to understand the subjective world of human experience" (Cohen, Manion \& Morrison, 2005, p. 22). Acknowledging the particular paradigm as the first step, it, subsequently, "... sets down the intent, motivation and expectations for the research", as well as the basis for the selection of the whole research design, including the research methodology and method(s) of research (Mackenzie \& Knipe, 2006, p. 2).

From an epistemological (knowledge) perspective, the research methodology employed in the research needed to provide propositional knowledge expressed in declarative sentences or indicative propositions on the issue or topic under investigation. A "5 Star" research methodology, initially introduced by Krüger (2014b), was again utilized, and is depicted in Figure 1. To recap, it involves five definite sequential steps which may also be cyclical, and entails the following: step 1 - putting forward a proposition; step 2 - listing the assumptions; step 3 - gathering evidence both in support of or against the proposition; step 4 - reviewing the evidence; and lastly, step 5 - justifying the conclusion. Within this paradigm, the outcome (knowledge) of the qualitative research is considered to be inductive theory characterized by subjective reality, as contextual, exploratory, expressed in words rather than numbers, with issues being complex and broad, and lastly, rather about understanding than control (Visagie, 2013, p. 19). The primary research method associated with the particular paradigm of the research was, thus, qualitative, in which secondary data and document analysis were utilized (Mackenzie et al., 2006, p. 5), and this was guided by the research control measures of trustworthiness which include credibility, transferability, dependability, conformability and authenticity (Visagie, 2012, pp. 8-9).

\section{THE "5 STAR" RESEARCH METHODOLOGY}

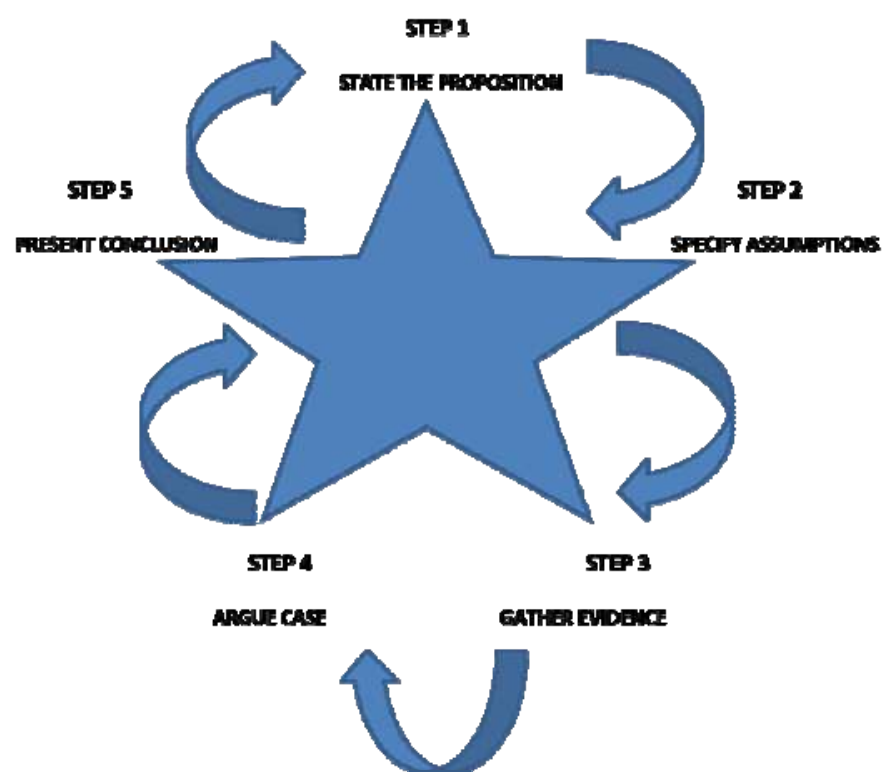

Fig. 1. "5 Star” research methodology 


\section{Research propositions and assumptions}

The two basic propositions of this research were formulated as follows:

1. Black economic empowerment (BEE) has a direct and indirect positive influence on the economic growth, the social development and political democracy of post-1994 South Africa.

2. Black economic empowerment (BEE) moves post-1994 South Africa away from a free-market economy (capitalism) to a greater state or government-controlled economy (socialism) with the possible eventuality of the adoption of communism.

The assumptions underlying this research were as follows:

1. Black economic empowerment (BEE) refers to the implementation of the provisions and regulations as contained in the Broad-Based Black Economic Empowerment (B-BBEE) Act 53 of 2003 and as amended by Act 46 of 2013.

2. The BEE codes of good practice that are currently applied are those issued by the Department of Trade and Industry (DTI) in accordance with section 9(1) of the B-BBEE Act (Government Gazette Vol. 500, No. 29617 on 9 February 2007, 96 pages). They are to be replaced with new codes of practice (Government Gazette Vol. 580, No. 36928 on 11 October 2013, 112 pages) and were expected to come into effect on 1 May 2015.

3. The evaluation of BEE and its influence (directly and indirectly) on the economic growth, social development and political democracy of post-1994 South Africa was to be considered from a both positive and negative attribute perspective with cases or manifestations (evidence) of both.

4. The possible movement in South Africa's ideology post-1994 from Western free-market capitalism towards pro-socialism and procommunism systems such as those practiced in Russia and China was to be considered from a Yes/No attribute perspective with cases or manifestations (evidence) of both.

5. Qualitative research through the collection of secondary data sources was used and there was no empirical data generation either through questionnaires or interviews (other than a personal interview with $\mathrm{Mr}$ Moeletsi Mbeki on 5 February 2015).

6. The guiding control measures include credibility (equivalent of validity in quantitative research) and trustworthiness (equivalent of reliability in quantitative research).

\section{Research data collection}

4.1. Proposition 1. The objective was to research the impact and/or influence (either directly or indirectly) that BEE has had on South Africa post-1994.
For this part of the qualitative research, the main secondary data sources that were consulted were (1) extracts from the BEE Act 53 of 2003 and its amendment Act 46 of 2013 (2) and e-newspaper articles dating back from the beginning of January until the end of December 2014, that the researcher considered to be related, either directly or indirectly, to BEE. The researcher was also fortunate to conduct a personal interview with Mr Moeletsi Mbeki (Mbeki, 2015), a well-respected political commentator, entrepreneur, and incidentally a brother of former president Thabo Mbeki in whose second term of office BEE legislation saw the light. He provided some unique insights into the first discussions regarding BEE with what he refers to as "Big Business" as far back as 1992 (Mbeki, 2011) even before the first democratic elections in 1994. When asked about what he felt BEE had achieved, he answered as follows (quoted verbatim with permission): "In my view, BEE has achieved the objectives that its architects, South Africa's big business, set out to achieve. Their primary objective was to co-opt powerful segments of the ANC leadership so that the structure of SA's business would not be tempered [sic] with in a significant way by the new ANC government. Eleven years since the passing of the BEE law in 2003 not only are the key cornerstones of SA business such as the Minerals Energy Complex migrant, labor system intact, but also large SA corporations have even been allowed by the ANC government to relocate their head offices and primary listing [sic] to London to help them to reduce their South Africa country risk exposure".

4.1.1. E-newspaper articles relating to the direct and indirect influence of BEE. Since the beginning of 2014, the researcher had on a daily basis scanned the headlines and collected e-newspaper articles that were thought to either be directly or indirectly related to the effects of BEE.

A recording and analysis technique was developed, referred to as QUALT2AM (QUALitative research of Topics and Themes Analysis Matrix) in which the articles relating to the research could be captured. The technique uses a matrix, where each article is captured in two dimensions, namely on the $\mathrm{x}$-axis, in one of ten topics and on the $y$-axis in one of 20 themes. The major topic headlines were those being reported at this time. Note: The high-profile criminal cases (both accused of murder) against para-Olympian Oscar Pistorius and Shrien Dewani were excluded, because they had no relevance to the current research topic. The ten topics were: (1) the Public Protector, Advocate Thuli Madonsela, and her efforts to increase public accountability in numerous cases reported to her; (2) Nkandla (President Jacob Zuma's private homestead which received security upgrades of some R246 million from taxpayers money; (3) internal government corruption, nepotism, ANC cadre 
employment and maladministration; (4) opposition political parties (the Democratic Alliance [DA] [22.2\% of voters in the May 2014 election], the Economic Freedom Fighters [EFF] [6.4\% of voters], the Inkatha Freedom Party [IFP] [2.4\% of voters], the National Freedom Party [NFP] [1.6\% of voters], etc.) and their attempts to ensure government accountability (Electoral Commission of South Africa [IEC], 2014); (5) the African National Congress's (62.2\% of voters in the May 2014 election) own political drive with its alliance partners notably the Congress of South African Trade Unions (COSATU) and the South African Communist Party (SACP) (ANC, 2016a); (6) BEE cases of success or failure; (7) E-tolling in Gauteng; (8) Eskom and the electricity crisis in South Africa; (9) the Marikana massacre where the South African police opened fire on striking miners on 16 August 2012 near Rustenburg, killing 34 and wounding close on another 80 miners in the aftermath, which was being investigated by the Farlam Commission of Inquiry; (10) the arms procurement deal dating back to 1998 where the goahead was given for the procurement of aircraft, corvettes and submarines at a cost of R29 billion, which is being investigated by the Seriti Commission of Inquiry for allegations of fraud, corruption, impropriety or irregularity and the related so-called "Zuma spy tapes", which led to charges of corruption against then deputy president Jacob Zuma being dropped and followed him being elected the third President (post-1994).

The 20 themes (the first 5 comprise the actual measurement basis in terms of the B-BBEE generic scorecard for compliance (DTI, 2016b) were as follows: (1) Ownership - 25/105 points; (2) Management Control - 15/105 points; (3) Skills Development - 20/105 points; (4) Enterprise and Supplier Development - 40/105 points; (5) Socioeconomic Development - 5/105 points; (6) socialism - Russian link or communism - Chinese link; (7) community services improvement; (8) African status in United Nations world bodies; (9) ANC political dominance; (10) labor unions and their activities; (11) corruption and self-enrichment; (12) nepotism and maladministration; (13) democracy and Western values; (14) privatesector entrepreneurship; (15) racial harmony and cohesiveness; (16) political opposition and minorities; (17) international status and exports; (18) productivity growth in the economy; (19) crime, lawlessness and anarchy; and (20) the judiciary, constitution and parliament.

As a "pre-test" to see whether the QUALT2AM technique could work and with the focus solely on BEE since the beginning of October 2014, some 33 articles were identified and coded. In these articles, a total of 151 incidents were recorded of which 34 or
23\% were deemed a positive influence (blue highlighting, but the majority, 117 or $77 \%$, were considered a negative influence (red highlighting) (see pictogram 1). Note: The overall picture that the table presents in terms of color is used to judge the impact of BEE. When it is predominantly red, it denotes the impact of BEE as negative, while blue is positive and yellow means no impact.

In 2016, a more comprehensive review of newspaper articles relating to BEE and its impact or influence on post-1994 South Africa stretching, as far back as January 2014 until January 2016, was conducted with the purpose of judging whether proposition 1 could either be accepted or rejected. In the case of the proposition being accepted, the majority of articles had to indicate a positive influence denoted by blue rather than red (negative influence). See Tables 1A, 1A (continued) (2014) and 1B, 1B (continued) (2015-2016).

4.2. Proposition 2. The objective of this second part of the research was to investigate how black economic empowerment (BEE) was possibly moving post-1994 South Africa ideologically away from a free-market economy (capitalism) to a greater state- or government-controlled economy (socialism) and possibly eventually to the adoption of communism. This movement ties in with the notion that many South Africans do not have full knowledge of the aims, goals and objectives of BEE and do not understand its ideological foundations. Under the heading "The ANC's other objectives", Jeffery $(2014$, p. 22) notes the following: "...the ANC had other objectives in mind" it [the ANC] with "... its allies in the Congress of South African Trade Unions [COSATU] and the South African Communist Party [SACP] - joint rulers with the ANC in the governing tripartite alliance - had long ago identified the NDR [National Democratic Revolution] as providing the shortest and most direct path to a socialist and the communist society". She again reiterates this point under the chapter heading "BEE and the Road Ahead" and writes as follows: “... [there is] a profound confusion about BEE goals. Most analysts assume that BEE is simply about remedying the past ..." but "... they [the ANC, COSATU and the SACP] naturally play up the supposedly remedial purpose of BEE", but " ... their real aim is to use it [BEE] as cover for the national democratic revolution [NDR]" and "her objective is not to provide redress, but rather to keep using BEE to reduce private sector autonomy, break down the market economy, and build state power and control" (Jeffery, 2014, p. 385).

In an analysis of the contribution of the Soviet Union to the so-called "struggle doctrines" of the ANC which preceded the post-1994 democratic South Africa and the Constitution of 1996, Hermann Giliomee (2013) believes there are many ANC cadres in key positions that are still committed to the doctrines that captivated 
the ANC while in exile. This came about through extensive interaction with Soviet bureaucrats in the 1960s and early 1970s who supported the SACP and ANC in the "liberation" in a two-stage revolution. According to Giliomee (2013), the "... two could be combined in the National Democratic Revolution (NDR), which meant a transition from national liberation to socialism ...".

\subsubsection{E-newspaper articles relating to the movement} of South Africa's ideology away from Western capitalism towards socialism and communism. For this part of the qualitative research, the main secondary data sources that were consulted were again newspaper articles that the researcher considered to be indicative of a movement in the prevailing political, economic and social ideology, dating back from December 2013 until January 2016. Note: In this analysis, evidence regarding proposition 2 (movement away from free-market economy to socialism and communism) was collected and recorded - see Table 2 and Table 2 (continued).

\section{Discussion}

BEE is the abbreviation for black economic empowerment. This policy is purely based on race. "Black people" are clearly defined in the Broad-Based Black Economic Empowerment Act, B-BBEE Act 53 of 2003 (and its amendment Act 46 of 2013), and includes everybody except so-called "white people". Anthea Jeffery, a political analyst, in probably the most comprehensive review of BEE to date, confirms this assertion in her observation that " ... the fact that BEE is based on racial identity makes the system still more difficult to criticize for fear of being labelled a racist or apartheid apologist" and she continues to argue that "... the racial foundation of BEE has had other consequences too ... it has breathed new life into the [concept of the] Population Registration Act of 1950 [appealed by the statute of 1991 by the former National Party government which was the government in South Africa between 1948 and 1994 when it was replaced by the African National Congress], under which all South Africans were previously classified as African, Coloured, Indian and White" (Jeffery, 2014, p. 25). She further cautions that “... BEE's emphasis on racial identity reinforces racial stereotypes and fosters polarization around race $\ldots$ also [it] undermines the core values of non-racialism and equity before the law, and opens the way to racial scapegoating ...", which she claims the ANC is also well aware of when they warned that "... affirmative action, if poorly implemented, could redistribute resentment and ... destroy social peace" (Jeffery, 2014, p. 26).

The generic definition of "black people" in the BBBEE Act is that they are those targeted as the sole beneficiaries of the legislation to empower black people. Many would immediately come out strongly in favor of the idea of "empowering black people who were previously disadvantaged by apartheid". But ten years since its first appearance in the B-BBEE Act the question can rightly be asked: Who has actually been empowered by BEE? Again Anthea Jeffery offers a perspective on the matter: "This helps to explain how a supposedly limited form of affirmative action has quietly morphed into a complex set of employment equity, BEE, and land reform rules that are cumulatively eroding business autonomy, undermining property rights, crippling public service efficiency, choking off direct investment, retarding economic growth and adding to a crisis of unemployment within the country", and she argues that these outcomes fly in the face of what BEE is intended to achieve "... instead, their benefits have gone mainly to a relatively small black elite - many of them well paid, but often ineffective public servants", but alarmingly " $\ldots$ it [BEE] has also fostered a toxic mix of inefficiency, waste and corruption that frequently causes great harm to the 19 million poor South Africans ..." of which "... the vast majority of these truly disadvantaged individuals have little or no prospect of ever gaining management posts, ownership deals, preferential contracts, or new small business ..." and critically, the "... most of them poor and unskilled, while more than 8 million of them are also unemployed" (Jeffery, 2014, pp. 22-23).

As can be observed from Tables $1 \mathrm{~A}$ and $1 \mathrm{~B}$, the articles listed and evaluated provide clear evidence that the majority are judged to be negative (red fill-in) in terms of the direct and indirect impact and influence of BEE on the growth of the economy, social development and political democracy in South Africa. Eighty-eight of the 110 articles (80\%) were judged as red (having a negative impact) and only $22(20 \%)$ as blue (having a positive impact) on South Africa. Proposition 1 is, thus, rejected, thereby concluding that BEE does have a direct and indirect negative affect on the economic growth, social development and political democracy of South Africa. This conclusion has significant implications for the way businesses are managed in South Africa in their quest for BEE compliance.

The ANC's economic/social and political ideology is still greatly influenced by core principles reflected in the ten clauses of the "Freedom Charter" (ANC, 2016b) despite the new Constitution of the Republic of South Africa of 1996 which the ANC under President Jacob Zuma's leadership “ ... repeatedly white-anted and undermined $\ldots$ by overlooking its prohibitions of racial discrimination and cadre deployment, flouting its emphasis on equality before the law, disregarding court judgements ...", according to Anthea Jeffery (Jeffery, 2015b). It was adopted by the South African Congress Alliance, which comprised several 
organizations including the ANC, the South African Indian Congress (SAIC), the Coloured People's Congress (CPC) and Congress of Democrats (COD) in Kliptown, on 26 June 1955 (Anonymous, 2016). The Freedom Charter “... was largely drawn up by white communists and was reportedly approved by Moscow prior to its adoption ... " and the "... ANC's current emphasis on the charter reflects the expanding influence of the SACP ..." and "... past and present members of the party [SACP] nevertheless make up some $40 \%$ of the current Cabinet ...". Many of the clauses are quite progressive in nature calling for "... equality before the law, freedom of speech and other civil liberties, equal education ...", but others reflect the strong influence of the SACP and even at that time were considered too socialistic such as that " ... the mineral wealth beneath the soil, the banks and monopoly industry shall be transferred to the people as a whole ...", and " ...all other industry and trade shall be controlled to assist the well-being of the people ..." and " $\ldots$ all the land shall be re-divided among those who work it to banish famine and land hunger ..." (Jeffery, 2015b). Note, however, that South Africa's newest left opposition party, the Economic Freedom Front (EFF) still subscribes to the Freedom Charter and even criticized the late former president Nelson Mandela in that "... the deviation from the Freedom Charter was the beginning of the selling out of the revolution". Interestingly, the EFF and ANC now compete as to who should be regarded as the real custodian of the Freedom Charter, while the SACP seems to have built up a hatred towards the EFF, which now parades itself as being more socialist than the SACP and uses Marxist rhetoric much more freely.

As can be observed from Table 2 and Table 2 (continued), the articles listed provide clear evidence that the majority were judged to confirm the movement of South Africa away from capitalism towards socialism and communism (majority blue fillin). Fifty-three of the 66 articles (80.3\%) were judged as blue (movement towards socialism) and only 13 $(19.7 \%)$ as red (indicative of supporting a free-market capitalist system) in South Africa. Proposition 2 is, thus, accepted, thereby concluding that South Africa is moving away from a free-market capitalism towards the adoption of socialism and communism. This conclusion has a much greater significance for managers should the free-market principles and profitdriven motive of businesses be substituted in favor of socialist and communist systems.

BEE more than anything since the founding of the Republic of South Africa, has placed it at a critical crossroad or junction. To continue with BEE means even more state or government intervention and increased command of the economy akin to socialist and communist states like Russia and China. Its rejection can steer the country away from the potential catastrophic disaster which may follow, considering the following quotes by Ayn Rand who unequivocally reminds us: "Capitalism has created the highest standard of living ever known on earth. The evidence is incontrovertible. The contrast between West and East Berlin is the latest demonstration, like a laboratory experiment for all to see. Yet, those who are loudest in proclaiming their desire to eliminate poverty are loudest in denouncing capitalism. Man's well-being is not their goal" (Rand, 1966a, p. 66).

"Capitalism has been called a system of greed - yet it is the system that raised the standard of living of its poorest citizens to heights no collectivist system has ever begun to equal, and no tribal gang can conceive of". Capitalism has been called nationalistic - yet it is the only system that banished ethnicity, and made it possible, in the United States, for men of various, formerly antagonistic nationalities to live together in peace.

Capitalism has been called cruel - yet it, brought such hope, progress and general good will that the young people of today, who have not seen it, find it hard to believe" (Rand, 1989, p. 129).

\section{Conclusion}

The purpose of the research was to investigate and analyze: (1) whether BEE had a direct or indirect positive influence on the growth of the economy, the social development and political democracy of post1994 South Africa; and (2) whether it was moving South Africa away from Western free-market capitalism and rather embracing more governmentcontrolled systems such as socialism eventually leading to communist rule (The Russian- and Chinabased doctrines).

The "5 Star" research methodology that was previously used in a successful research project guided the research in the utilization of an exploratory qualitative research method in which only secondary data were consulted. The literature sources were selected accredited journal articles, e-newspaper articles and various sources accessed and downloaded from the Internet. For the start of the research, a conceptual framework named QUALT2AM was developed on the basis of a matrix dimension of topics (horizontal) and themes (vertical) in order to consider whether BEE should be considered a solution or rather as the problem.

In continuing the research, e-newspaper articles with statements, quotes or opinions were collected and documented as evidence to judge whether the two proposition could be accepted or rejected. It is acknowledged that this judgement is that of the researcher alone, but based on exact extracts (see 
the motivation column in Tables 1A, 1B and 2) of the particular article. Note: The researcher did apply some form of validation as the initial e-articles were judged in October 2014 and again in January 2016 and the judgement then and later showed few discrepancies or deviations.

BEE is undoubtedly more distributive ("share what is available among all - hopefully equal"), perhaps even punitive ("take what is available, redistribute only what you want, but keep as much as possible for the governing elite") rather than an expansive ("create and produce more for all to benefit based on contribution and effort") policy which has a negative direct and indirect impact on economic growth, social development and political democracy in South Africa. BEE should, thus, be scrapped. BEE further seems to assimilate the socialist and communist ideologies rather than capitalism's promise. If this is not the path South Africa wants to be on (seeing that its major trading partners who represent $85 \%$ sand $90 \%$ of South Africa's foreign direct and non-direct investment as at December 2013) (Jeffery, 2015), the country through the current ANC leadership is clearly moving away from Western countries such as Europe, America and aligning itself with Russia and China. It may not be too late to "turn the ship around" so to speak, especially if the ANC can rid itself of the current pro-socialist and pro-communist leaders in its National Executive Committee (NEC), as well as other prominent positions in its leadership structures (which include ministers and deputy ministers) of which many such occupants are unwavering, declared SACP comrades.
The last point warrants a national debate on whether South Africa will still have a free-market economy or state- and government-controlled economy, thereby turning its back on capitalism and fully embracing socialism leading to communism. Anthea Jeffery (2015b) underscores this point by arguing that " ... instead of blindly following the failed socialist prescriptions of a long outdated document [referring to the Freedom Charter], the ANC should recognize the Constitution [of the Republic of South Africa, 1996] as its 'bible', uphold its provisions and urgently implement the market-based reforms increasingly vital to investments, growth and jobs".

In conclusion, another two quotations by Ayn Rand dating back to the early 1960s may add to this vital debate:

"The only proper, moral purpose of a government is to protect man's rights, which means: to protect him from physical violence - to protect his right to his own life, to his own liberty, to his own property and to the pursuit of his own happiness. Without property rights, no other rights are possible" (Rand, 1961, p. 183).

"When one observes the nightmare of the desperate efforts made by hundreds of thousands of people struggling to escape from the socialized countries of Europe, to escape over barbed-wire fences, under machine-gun fire - one can no longer believe that socialism, in any of its forms, is motivated by benevolence and by the desire to achieve men's welfare" (Rand, 1964, p. 86).

\section{References}

1. ANC. (2016a). Tripartite Alliance. Available at: http://www.anc.org.za/themes.php?t=Tripartite\%20Alliance. Accessed on 26 January 2016.

2. ANC. (2016b). The freedom charter. Available at: http://www.anc.org.za/show.php?id=72. Accessed on 1 February 2016.

3. BBC. (2014). South Africa profile - Timeline. Available at: http://www.bbc.com/news/world-africa-14094918. Accessed on 11 November 2014.

4. South African History Online. (2016). The Freedom Charter is adopted in Kliptown. Available at: http://www.sahistory.org.za/dated-event/freedom-charter-adopted-kliptown. Accessed on 4 February 2016.

5. Cohen, L., Manion, L. \& Morrison, K. (2005). Research methods in education. $5^{\text {th }}$ edition. UK: Taylor \& Francis e-Library.

6. Department of Trade and Industry. (2016a). Economic Empowerment. Available at: http://www.dti.gov.za/economic_empowerment/bee.jsp. Accessed on 26 January 2016.

7. Department of Trade and Industry. (2016b). Government gazette Staatskoerant. Available at: https://www.thedti.gov.za/economic_empowerment/docs/code_gud_practice10102013.pdf. Accessed on 26 January 2016.

8. Electoral Commission of South Africa. (2014). 2014 National and Provincial Elections: National results. Available at: http://www.elections.org.za/content/elections/results/2014-national-and-provincial-elections--national-results/. Accessed on 26 January 2016.

9. Giliomee, H. (2013). The Soviets and the ANC: An enduring legacy? Available at: http://www.politicsweb.co.za/news-and-analysis/the-soviets-and-the-anc-an-enduring-legacy. Accessed on 26 January 2016.

10. Jeffery, A. (2014). BEE: Helping or hurting? Cape Town: Tafelberg.

11. Jeffery, A. (2015a). Anthea Jeffery: Economic needs must trump anti-Western ideology. Available at: http://www.fin24.com/BizNews/Anthea-Jeffery-Economic-needs-must-trump-anti-Western-ideology-20150903. Accessed on 4 September 2015. 
12. Jeffery, A. (2015b). Anthea Jeffrey: Constitution should be ANC's bible - not 60 year old Freedom Charter. Available at: http://www.fin24.com/BizNews/Anthea-Jeffrey-Constitution-should-be-ANCs-bible-not-60-yearold-Freedom-Charter-20150624. Accessed on 4 February 2016.

13. Krüger, L.P. (2014a). South African managers' perceptions of black economic empowerment (BEE): A "sunset" clause may be necessary to ensure future sustainable growth, Southern African Business Review, 18 (1), pp. 80-99.

14. Krüger, L.P. (2014b). Broad-based black economic empowerment (B-BBEE) in South Africa: A moral and ethical management perspective, Problems and Perspectives in Management, 12 (4), pp. 442-456.

15. Mackenzie, N. \& Knipe, S. (2006). Research dilemmas: paradigms, methods and methodology, Issues in Educational Research, 16, pp. 1-10.

16. Mbeki, M. (2011). Interesting article by Moeletsi Mbeki (Thabo Mbeki's brother). Available at: https://groups.google.com/forum/\#!msg/communist-university/CZPXgVekyIk/uaDM04i6CVcJ. Accessed on 26 January 2016.

17. Mbeki, M. (2015). Personal interview with Mr Moeletsi Mbeki by Prof. Louis P. Krüger. Lonehill: Johannesburg on 5 February 2015.

18. Rand, A. (1961). For the new intellectual: Galt's speech. Available at: http://aynrandlexicon.com/lexicon/government/3.html. Accessed on 26 January 2016.

19. Rand, A. (1964). The virtue of selfishness. Available at: https://www.aynrand.org/campus/globals/lexiconrepository/s/soviet-russia. Accessed on 26 January 2016.

20. Rand, A. (1966). Capitalism: the unknown ideal. Faith and force: the destroyers of the modern world. Available at: http://aynrandlexicon.com/lexicon/capitalism.html. Accessed on 26 January 2016.

21. Rand, A. (1989). The voice of reason: essays in objectivist thought. Available at: http://aynrandlexicon.com/lexicon/capitalism.html. Accessed on 4 February 2016.

22. SAPA (2014a). Corruption is a cancer - ANC. Available at: http://www.news24.com/SouthAfrica/Politics/Corruption-is-a-cancer-ANC-20140623. Accessed on 24 June 2014.

23. Visagie, R. (2012). Methodological rigour and ethics of accountability within a qualitative framework, Emoyeni Research Collaborations, pp. 8-12.

24. Visagie, R. (2013). Choosing among the three paradigms, Emoyeni Research Collaborations, p. 19.

\section{Appendix}

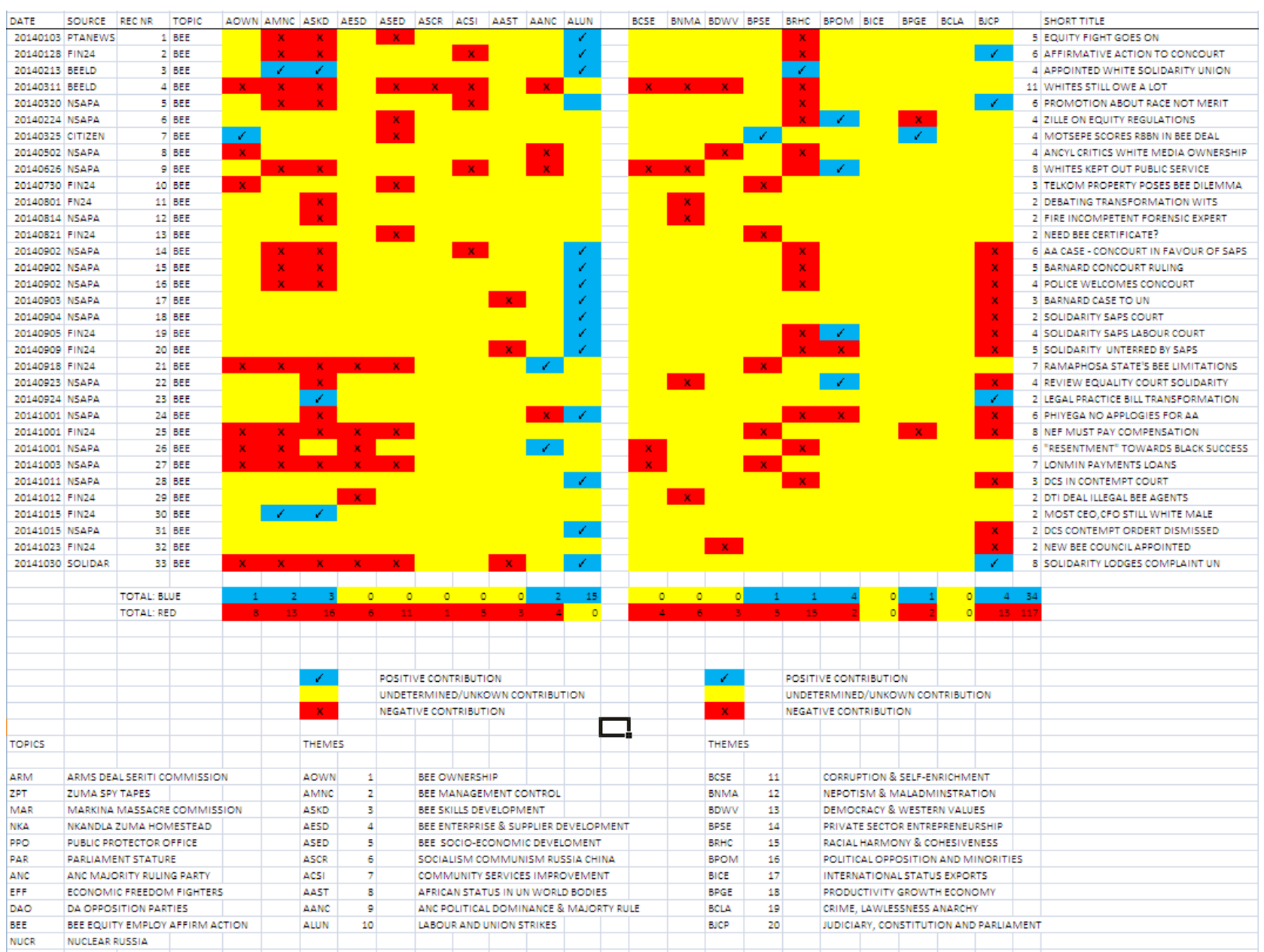

Pictogram 1. QUALT2AM BEE October 2014 
Table 1A. Impact of BEE (January-December 2014)

\begin{tabular}{|c|c|c|c|}
\hline \multirow{2}{*}{ № } & \multirow{2}{*}{ Title } & Year & \multirow{2}{*}{ Motivation } \\
\hline & & 2014 & \\
\hline 1 & Equity fight rages on & $\mathbf{x}$ & Regional and national demographics employment equity considered \\
\hline 2 & ANC vows bitter anti-graft fight & $\mathbf{x}$ & Anc to power 20 years - still persistent poverty \\
\hline 3 & ANC loyalty is support of a predatory state & $\mathrm{x}$ & People right connections loot the state \\
\hline 4 & ANC report admits party has failed & $\mathrm{X}$ & Anc concede they failed to meet delivery targets \\
\hline 5 & Affirmative action case goes to concourt & $\mathrm{x}$ & Appeal constitutional court against discrimination on basis of race \\
\hline 6 & Our duty to rebuild ubuntu: zuma & $\checkmark$ & Work together in the spirt of ubuntu and respect rule of law \\
\hline 7 & Kry pos, al is hy wit: english - gets post even though he is white & $\checkmark$ & Gets senior post after appeal even though he is white \\
\hline 8 & Apartheid created sa's problems - zuma & $\checkmark$ & Apartheid created problems of institunionalised racism \\
\hline 9 & Kommentaar: wittes skuld nog baie: english - whites owe a lot still & $\mathrm{X}$ & Bee benefitted anc cadres unduly - corruption and waste millions \\
\hline 10 & Promotion about race, not merit, concourt hears & $\mathrm{x}$ & Decision not to promote based on race not merit \\
\hline 11 & SA has a good story to tell, says zuma & $\checkmark$ & Legacy apartheid huge and backlogs are massive \\
\hline 12 & Mbeki: freedom being abused for personal gain & $\mathbf{x}$ & Exploit freedom for personal aggrandisement \\
\hline 13 & Zille warns on equity regulations & $\mathrm{x}$ & Ee regulations impact on jobs in westem cape if implemented - demographics \\
\hline 14 & Motsepe scores r8bn in sanlam BEE deal & $\checkmark$ & Made over r8bn from r200m in sanlam ubuntu-botho-bee deal \\
\hline 15 & Don't be short-sighted about b-bbee codes & $\checkmark$ & Compliance brings b-bbee support mutual gains real innovation \\
\hline 16 & SA sliding into crony capitalism - naidoo & $\mathbf{x}$ & Service delivery marred by corruption systems fail by incompetence and mediocrity \\
\hline 17 & Only voters can say anc has problem - ramaphosa & $\checkmark$ & Voters will say how they love the party - anc lost support \\
\hline 18 & SA still racially divided - ramaphosa & $\mathbf{x}$ & SA still gender and racially divided - socially cohesive to close racial gap \\
\hline 19 & Anc has transformed SA - makhura & $\checkmark$ & Anc moving country forward - most unequal country in the world? \\
\hline 20 & The anc there to serve - ramaphosa & $\checkmark$ & We are your servants - we listen to you \\
\hline 21 & Ancyl concerned about white media ownership & $\mathrm{x}$ & Control counter-revolutionary whites - anc must own a newspaper \\
\hline 22 & Corruption is a cancer - anc & $\mathbf{x}$ & Anc officials allegation of fraud, corruption and money laundering \\
\hline 23 & Sairr: whites kept out of public service & $\mathbf{x}$ & Encouraged to keep posts vacant rather than fill with whites \\
\hline 24 & Telkom's property poser & $\mathrm{x}$ & Divest telkom's properties delayed by b-bbee considerations \\
\hline 25 & Jimmy manyi, adam habib debate transformation & $\mathbf{x}$ & Habib debates manyi on equitable representation as a legal issue at wits \\
\hline 26 & Nene: nigeria's success a warning to sa & $\mathbf{x}$ & Supply side disruptions have plagued sa's economy \\
\hline 27 & Government has failed & $x$ & Sit secure in parliament and cover up latest scandals on corruption \\
\hline 28 & The black BEE rainbow nation & $\mathrm{x}$ & Jobless whites are not even allowed to apply for work \\
\hline 29 & Capitalists are using you, protest tell ramaphosa & $\mathrm{x}$ & You are a sell-out - ramaphosa must be charged for murdering african people \\
\hline 30 & Fire incompetent people - forensic expert & $\mathbf{x}$ & Employ competent people ... not people who meet whatever crazy criterion \\
\hline 31 & Never forget where we come from - zuma & $\checkmark$ & We must be reminded where we come from - under apartheid \\
\hline 32 & In need of a BEE certificate? & $\mathbf{x}$ & Valid BEE certificate - exempt micro enterprises must still engage b-bbee \\
\hline 33 & Mantashe: private sector must deal with past & $\checkmark$ & Private sector too slow to transform - where state is in charge there is progress \\
\hline 34 & Aa case: concourt rules in favour of police & $\mathbf{x}$ & Appeal sca decision upheld and set aside - non-promotion on basis of race accepted \\
\hline 35 & Barnard disappointed with concourt ruling & $\mathrm{X}$ & Barnard against the way they implemented aa - SA best constitution - no discrimination \\
\hline 36 & Saps welcomes barnard concourt ruling & $\mathrm{X}$ & Saps welcome the judgement of concourt - discrimination accepted \\
\hline 37 & Ex-cop barnard now turns to un & $\mathrm{x}$ & Take battle to un and ilo - ee laws not with international convensions on racism \\
\hline 38 & Solidarity to take saps to court & $\mathbf{x}$ & Force saps to consult with trade union goes to labour court \\
\hline 39 & Solidarity to court over saps labour talks & $\mathrm{X}$ & Solidarity to order saps to consult over aa plan \\
\hline 40 & The rise of anc and the decline of black excellence & $\mathrm{X}$ & Current crop of anc leaders would not qualify - blatant ineptitude \\
\hline 41 & Solidarity undeterred by saps equity case & $\mathrm{X}$ & Cases against racial minority groups to continue \\
\hline 42 & Minority report: policing black incompetence & $\mathrm{x}$ & Divisive concourt ruling - reflects old cracks haunting SA as nation \\
\hline 43 & Divided we fall - prosperity is a formula not a political structure & $x$ & Majority must grasp the dynamics of self motivation and importance of education \\
\hline 44 & The race game - democracy in flagrante delicto & $\mathrm{X}$ & Narrative of racial equality and population proportionality is nonsense \\
\hline 45 & Ramaphosa admits state's BEE limitations & $\mathrm{X}$ & Be candid about limitations of BEE policies - push agenda transformation \\
\hline 46 & Back to basics for local government - zuma & $\checkmark$ & Services to offer in professional manner and review tender systems \\
\hline 47 & Open letter to "our" politicians and parliament (institutions) & $\mathrm{X}$ & Governing party fails to separate state, government and the anc party \\
\hline 48 & Minister to review radebe decision - solidarity & $\mathbf{X}$ & Review decision not to appoint white man \\
\hline 49 & Zuma signs legal practice bill & $\checkmark$ & Transformation of legal profession - increase skills irrespective of race \\
\hline 50 & Phiyega: no apologies for affrimative action & $\mathbf{x}$ & Do not be apologetic - redress past injustices within confines of constitution \\
\hline 51 & Nef must pay 'sorry money', says madonsela & $\mathrm{x}$ & Money withdrawn not "black person" under BEE - citizenship should be checked upfront \\
\hline 52 & Mantashe: resentment towards black success & $\mathrm{X}$ & Conclusion of black success - must be corrupt or is connected to the anc \\
\hline 53 & Lonmin payments were loans, says shanduka & $\mathbf{x}$ & Interest free loans prevent company default - endagered lonmin mining license \\
\hline 54 & Armed struggle against anc government is becoming inevitable & $\mathrm{x}$ & Spirit in the post 1994 anc leadership - despicable rot \\
\hline
\end{tabular}


Table 1A (cont.). Impact of BEE (January-December 2014)

\begin{tabular}{|l|l|c|l|}
\hline \multirow{2}{*}{ № } & \multicolumn{1}{|c|}{ Title } & Year & \multirow{2}{*}{ Motivation } \\
\cline { 3 - 3 } & & 2014 & \\
\hline 55 & Truth about white monopoly & $\mathrm{X}$ & Proven in history and present day - BEE is a bad thing \\
\hline 56 & Dcs in contemp of court over jobs - union & $\mathrm{X}$ & Correctional services not abided by court decision to observe regional demograhics \\
\hline 57 & Big problem with illegal BEE agens - dti & $\mathrm{X}$ & lllegal verification agents issue fraudulant BEE certificates \\
\hline 58 & The eff's petty militarism versus parliament: south africa & $\mathrm{X}$ & Anc knows its wrongs - councillors emerge in opulance aloofness \\
\hline 59 & Most ceos, cfos still white males - survey & $\checkmark$ & Through thuthuka bursary scheme hundreds of potential black cas \\
\hline 60 & Solidarity's contempt of court application dismissed & $\checkmark$ & Dcs not wiffully failed with appointments national and regional demographics \\
\hline 61 & Zuma appoints new BEE council members & $\mathrm{X}$ & Instituitional advisory council to overall monitoring of b-bbee \\
\hline 62 & Solidariteit le klag by vn: englsih - solidarity lays charge at united nations & $\mathrm{X}$ & SA government programme aa not in line with un resolution \\
\hline 63 & Nzimande lashes out at sabc chair & $\mathrm{X}$ & Sabc person lying about having a degree \\
\hline 64 & Tutu laments sa's "time warp" & $\mathrm{X}$ & Mechanisms to redistribute wealth have failed \\
\hline 65 & Symptoms of the 'nongqawuse syndrome' in south africa & $\mathrm{X}$ & Nongqawuse tendencies of promulgating populist self-destruction \\
\hline 66 & They have animals in africa & $\mathrm{X}$ & Claim an undisturbed africa as perfect before invasion of white man \\
\hline
\end{tabular}

Table 1A (references). Impact of BEE (Jan-Dec 2014)

\begin{tabular}{|c|c|c|c|c|}
\hline № & Date & Source & Author & Reference \\
\hline 1 & 03.01 .2014 & $\begin{array}{l}\text { Pretoria } \\
\text { news }\end{array}$ & & http://pretorianews.newspaperdirect.com/epaper/viewer.aspx \\
\hline 2 & 11.01 .2014 & NEWS24 & & http://www.news24.com/SouthAfrica/Politics/ANC-vows-bitter-anti-graft-fight-20140111 \\
\hline 3 & 23.01.2014 & $\begin{array}{l}\text { lol Pretoria } \\
\text { news }\end{array}$ & Richard Pithouse & http://uwww.iol.co.za/pretoria-news/opinion/anc-loyalty-is-support-of-a-predatory-state-1.1635955 \\
\hline 4 & 27.01 .2014 & lol news & L. Seale \& P. Rampedi & http://www.iol.co.za/news/politics/anc-report-admits-party-has-failed-1.1637176 \\
\hline 5 & 29.01 .2014 & FIN24 & & http://www.fin24.com/Economy/Affirmative-action-case-goes-to-ConCourt-20140128 \\
\hline 6 & 13.02 .2014 & NEWS24 & & http://www.news24.com/SouthAfrica/Politics/Our-duty-to-rebuild-Ubuntu-Zuma-20140213 \\
\hline 7 & 13.02.2014 & BEELD & Sonja Carstens & http://beeld.com/nuus/2014-02-13-kry-pos-al-is-hy-wit \\
\hline 8 & 14.02 .2014 & NEWS24 & & http://www.news24.com/SouthAfrica/Politics/Apartheid-created-SAs-problems-Zuma-20140214 \\
\hline 9 & 11.03 .2014 & BEELD & S. Terreblanche & http://www.beeld.com/opinie/2014-03-11-kommnetaar-wittes-skuld-nog-baie \\
\hline 10 & 20.03 .2014 & NEWS24 & & http://www.news24.com/SouthAfrica/News/Promotion-about-race-not-merit-ConCourt-hears-20140320 \\
\hline 11 & 21.03 .2014 & NEWS24 & & http://www.news24.com/SouthAfrica/News/SA-has-a-good-story-to-tell-says-Zuma-20140321 \\
\hline 12 & 24.03 .2014 & NEWS24 & & http://www.news24.com/SouthAfrica/News/Mbeki-Freedom-being-abused-for-personal-gain-20140324 \\
\hline 13 & 25.03 .2014 & NEWS24 & & http://www.news24.com/SouthAfrica/Politics/Zille-warns-on-equity-regulations-20140324-5 \\
\hline 14 & 25.03 .2014 & CITIZEN & Riaz Gardee & http://citizen.co.za/148953/motsepe-scores-r8bn-in-sanlam-bee-deal/ \\
\hline 15 & 11.04 .2014 & FIN24 & C. Wijnberg & http://m.news24.com/fin24/Entrepreneurs/News/Dont-be-short-sighted-about-BBBEE-codes-20140411 \\
\hline 16 & 17.04 .2014 & NEWS24 & & http://www.news24.com/Elections/News/SA-sliding-into-crony-capitalism-Naidoo-20140417 \\
\hline 17 & 20.04 .2014 & NEWS24 & & http://www.news24.com/Elections/News/Only-voters-can-say-ANC-has-problem-Ramaphosa-20140420 \\
\hline 18 & 29.04 .2014 & NEWS24 & & http://www.news24.com/Elections/News/SA-still-racially-divided-Ramaphosa-20140429 \\
\hline 19 & 30.04 .2014 & NEWS24 & & http://www.news24.com/Elections/News/ANC-has-transformed-SA-Makhura-20140430 \\
\hline 20 & 01.05 .2014 & NEWS24 & & http://news24.com/Elections/News/The-ANC-there-to-serve-Ramaphosa-20140430 \\
\hline 21 & 02.05 .2014 & NEWS24 & & http://www.news24.com/Electiosn/News/ANCYL-concerned-about-white-media-ownership-20140502 \\
\hline 22 & 23.06 .2014 & NEWS24 & & http:///www.news24.com/SouthAfrica/Politics/Corruption-is-a-cancer-ANC-20140623 \\
\hline 23 & 26.06 .2014 & NEWS24 & & http://www.news24.com/SouthAfrica/News/SAIRR-Whites-kept-out-of-public-service-20140626 \\
\hline 24 & 30.07 .2014 & FIN24 & & http://www.fin24.com/Tech/Opion/Telkoms-property-poser-20140730 \\
\hline 25 & 01.08 .2014 & FIN24 & M. Smallhorne & http://www.fin24.com/Economy/Debating-transformation-20140801 \\
\hline 26 & 01.08.2014 & FIN24 & & http://www.fin24.com/Economy/Nene-Nigerias-success-a-warning-to-SA-20140801 \\
\hline 27 & 05.08.2014 & NEWS24 & D. Wadsworth & http://www.news24.com/MyNews24/Government-has-failed-20140805 \\
\hline 28 & 08.08 .2014 & NEWS24 & Mav Ricsa & http://www.news24.com/MyNews24/The-Black-BEE-rainbow-nation-20140808 \\
\hline 29 & 12.08 .2014 & NEWS24 & & http://www.news24.com/SouthAfrica/News/Capitalists-are-using-you-protests-tell-Ramaphosa-20140812 \\
\hline 30 & 14.08 .2014 & NEWS24 & & http://www.news24.com/SouthAfrica/Fire-incompetent-people-forensic-expert-20140814 \\
\hline 31 & 15.08 .2014 & NEWS24 & & http://www.news24.com/SouthAfrica/News/Never-forget-where-we-come-from-Zuma-20140815 \\
\hline 32 & 21.08 .2014 & FIN24 & & http://www.fin24.com/Entrepreneurs/Question-And-Answers/ln-need-of-a-BEE-certificate-20140821 \\
\hline 33 & 22.08 .2014 & FIN24 & & http://www.fin24.com/Economy/Mantashe-Private-sector-must-deal-with-past-20140822 \\
\hline 34 & 02.09.2014 & NEWS24 & & http://www.news24.com/SouthAfrica/News/AA-case-ConCourt-rules-in-favour-of-police-20140902 \\
\hline 35 & 02.09 .2014 & NEWS24 & & http://www.news24.com/SouthAfrica/News/Barnard-disappointed-with-ConCourt-ruling-20140902 \\
\hline 36 & 02.09.2014 & NEWS24 & & http://wwww.news24.com/SouthAfrica/Nes/SAPS-welcomes-Barnard-ConCourt-ruling-20140902 \\
\hline 37 & 03.09 .2014 & NEWS24 & & http://wwww.news24.com/SouthAfrica/News/Ex-cop-Barnard-now-turns-to-UN-20140903 \\
\hline 38 & 04.09 .2014 & NEWS24 & & http://www.news24.com/SouthAfrica/News/Solidarity-to-take-SAPS-to-court-20140904 \\
\hline 39 & 05.09 .2014 & FIN24 & & http://www.fin24.com/Economy/Solidarity-to-court-over-Saps-labour-talks-20140905 \\
\hline
\end{tabular}


Table 1A (references) (cont.). Impact of BEE (Jan-Dec 2014)

\begin{tabular}{|c|c|c|c|c|}
\hline № & Date & Source & Author & Reference \\
\hline 40 & 05.09.2014 & NEWS24 & Matome Letsoalo & http://voices.news24.com/matome-letsoalo/2014/09/rise-anc-decline-black-excellence/ \\
\hline 41 & 09.09 .2014 & FIN24 & & http://www.fin24.com/Economy/Solidarity-undeterred-by-Saps-equity-case-20140909 \\
\hline 42 & 09.09 .2014 & NEWS24 & Tshethe Litheko & http://voices.news24.com/tshethe-litheko/2014/09/minority-report-policing-black-incompetence/ \\
\hline 43 & 15.09 .2014 & NEWS24 & A. Graeme Wilson & http://www.news24.com/MyNews24/Divided-we-fall-Prosperity-is-a-formula-not-a-political-structure-20140914 \\
\hline 44 & 16.09 .2014 & NEWS24 & Martin Warburg & http://voices.news24.com/martin-warburg/2014/09/race-game-democracy-flagrante-delicto/ \\
\hline 45 & 18.09 .2014 & FIN24 & & http://www.fin24.com/Ramaphosa-admits-states-BEE-limitations-20140918 \\
\hline 46 & 18.09 .2014 & NEWS24 & & http://www.news24.com/SouthAfrica/News/Back-to-basics-for-local-government-Zuma-20140918 \\
\hline 47 & 19.09 .2014 & NEWS24 & Siiphamandlah & http://www.news24.com/MyNews24/Open-Letter-to-OUR-Politicians-and-Parliament-Institutions-20140919 \\
\hline 48 & 23.09 .2014 & NEWS24 & & http://www.news24.com/SouthAfrica/News/Minister-to-review-Radebe-decision-Solidarity-20140923 \\
\hline 49 & 24.09 .2014 & NEWS24 & & http://www.news24.com/SouthAfrica/News/Zuma-signs-legal-pratice-bill-20140924 \\
\hline 50 & 01.10 .2014 & NEWS24 & & http://www.news24.com/SouthAfrica/News/Phiyega-No-apologies-for-affirmative-action-20141001 \\
\hline 51 & 01.10 .2014 & FIN24 & & http://www.fin24.com/Economy/NEF-must-pay-sorry-money-says-Madonsela-20141001 \\
\hline 52 & 01.10 .2014 & NEWS24 & & http://www.news24.com/SouthAfrica/News/Mantashe-Resentment-towards-black-success-20141001 \\
\hline 53 & 03.10 .2014 & FIN24 & & http://www.fin24.com/Companies/Mining/Lonmin-payments-were-loans-says-Shanduka-20141003 \\
\hline 54 & 03.10 .2014 & NEWS24 & Matome Letsoalo & http://voices.news24.com/matome-letsoalo/2014/10/armed-struggle-anc-government-becoming-inevitable/ \\
\hline 55 & 05.10 .2014 & NEWS24 & L. Jnr Jooste331 & http://www.news24.com/MyNews24/Truth-about-white-monopoly-20141005 \\
\hline 56 & \begin{tabular}{|l|l|}
11.10 .2014 \\
\end{tabular} & NEWS24 & & http://www.news24.com/SouthAfrica/News/DCS-in-contempt-of-court-over-jobs-union-20141011 \\
\hline 57 & 12.10 .2014 & FIN24 & & http://www.fin24.com/Economy/Big-problem-with-illegal-BEE-agents-dti-20141012 \\
\hline 58 & 15.10 .2014 & NEWS24 & Brad Cibane & $\begin{array}{l}\text { http://voices.news24.com/brad-cibane/2014/10/economic-freedom-fighters-petty-militarism-will-break-south- } \\
\text { africas-democracy/ }\end{array}$ \\
\hline 59 & 15.10 .2014 & FIN24 & & http://www.fin24.com/Economy/Most-CEOs-CFOs-still-white-males-survey-20141015 \\
\hline 60 & 15.10 .2014 & NEWS24 & & http://www.news24.com/SouthAfrica/News/Solidaritys-contempt-of-court-application-dismissed-20141015 \\
\hline 61 & 23.10 .2014 & FIN24 & & http://www.fin24.com/Economy/Zuma-appoints-new-BEE-council-members-20141023 \\
\hline 62 & 30.10 .2014 & Solidarity & & $\begin{array}{l}\text { https://regsfonds.solidariteit.co.za/solidariteit-le-klagte-by-vn-teen-die-suid-afrikaanse-regering-oor-die- } \\
\text { nienakoming-van-vn-resolusie/ }\end{array}$ \\
\hline 63 & 02.11 .2014 & NEWS24 & & http://www.news24.com/SouthAfrica/News/Nzimande-lashes-out-at-SABC-chair-20141102 \\
\hline 64 & 12.12 .2014 & NEWS24 & & http://www.news24.com/SouthAfrica/News/Tutu-laments-SAs-time-warp-20141212 \\
\hline 65 & 15.12 .2014 & NEWS24 & Fairchance Ncube & http://voices.news24.com/fairchance-ncube/2014/12/symptoms-nongqawuse-syndrome-south-africa/ \\
\hline 66 & 20.12 .2014 & NEWS24 & Celma Costa & http://voices.news24.com/celma-costa/2014/12/they-have-animals-in-africa/ \\
\hline
\end{tabular}

Table 1B. Impact of BEE (Jan 2015 - Jan 2016)

\begin{tabular}{|c|c|c|c|}
\hline \multirow{2}{*}{ № } & \multirow{2}{*}{ Title } & Year & \multirow{2}{*}{ Motivation } \\
\hline & & 2015 & \\
\hline 67 & Anglo could pull plug on eskom coal supply & $\mathrm{X}$ & Government require that blacks own at least $55 \%$ of a supplier \\
\hline 68 & Economy is not working, patel told & $\mathrm{X}$ & The BEE thing that has been done ... is not solving economic problems \\
\hline 69 & SA BEE criticism casts dark cloud on mining & $X$ & Forced to sell $26 \%$ of assets to black south africans to narrow disparities \\
\hline 70 & 'Flaccid dti lacks courage' & $\mathrm{x}$ & Bee issues badly managed by the dti and lacks courage to champion transformation \\
\hline 71 & Farewell rainbow nation & $\mathrm{X}$ & Black economic empowerment system has failed dismally to create jobs \\
\hline 72 & Government in denial about corruption - alliance & $\mathrm{X}$ & Diversion of billions of rands from delivery into hands of the elite \\
\hline 73 & Business must step up to plate as dti dithers on beee & $\mathrm{x}$ & Onus remains on big business to transform its supply chains \\
\hline 74 & The true value of sa's BEE deals revealed & $\checkmark$ & Amount generated shows that BEE deals do not create value are false \\
\hline 75 & $\begin{array}{l}\text { Time to halt BEE - replace with "economic empowerment for the } \\
\text { disadvantaged" }\end{array}$ & X & Warned against BEE ownership requirements will deter foreign direct investment \\
\hline 76 & $\begin{array}{l}\text { Transformation and "unintended consequences" - subverting } \\
\text { democracy }\end{array}$ & X & Transformation coercive, racially driven and carry's costs to the economy \\
\hline 77 & Key interventions did not shift economy - anc & $\mathrm{X}$ & Acceleration of b-bbee as it has not shifted the economy \\
\hline 78 & Corruption a cancer to development & $\mathrm{X}$ & Corruption a cancer to development objectives - illicit capital outflows \\
\hline 79 & $\begin{array}{l}\text { Manyi: 'white-owned' business has betrayed mandela's reconciliation } \\
\text { legacy }\end{array}$ & X & Government to ensure that the consequences for not doing $\mathrm{BEE} \ldots$ \\
\hline 80 & SA inc only as strong as its leadership & $\mathbf{x}$ & Invariably negative and often scathing in governing by anc \\
\hline 81 & Vavi: corruption at root of eskom load shedding & $\mathrm{x}$ & Bee suppliers earning more than double the profits with zero value added \\
\hline 82 & Phosa slates BEE policy & $\mathrm{X}$ & Millions black people see only a few that largely benefitted from tenderpreneurship \\
\hline 83 & "Transformation", provocation and confrontation: insurrection looms & $\mathbf{X}$ & Included affirmative action and BEE benefitting minority low productivity interests \\
\hline 84 & Kgalema motlanthe calling it as it is & $\checkmark$ & Rot of corruption spreads across the state and society \\
\hline 85 & Mathews phosa takes swipe at zuma & $\checkmark$ & Form united front against corruption - the country and its people must come first \\
\hline 86 & $\begin{array}{l}\text { How the world sees us: tim knight- SA's slide from madiba to zuma. oh } \\
\text { boy. }\end{array}$ & $X$ & SA further away from democratic dream - zuma believes $\mathrm{SA}$ is his personal fiefdom \\
\hline
\end{tabular}


Table 1B (cont.). Impact of BEE (Jan 2015 - Jan 2016)

\begin{tabular}{|c|c|c|c|}
\hline № & Title & Year & Motivation \\
\hline 87 & 'Zulu king was reflecting on apartheid, not defending it' & $\mathrm{X}$ & Black people destroy gains of the past - good and bad in democratic government \\
\hline 88 & Trevor manuel blasts zuma's finmin blunder, asks tough questions & $\mathrm{X}$ & Dismissing minister - breakdown in trust SA electorate, markets and business \\
\hline 89 & Herman mashaba responds: anc failed the people. time for change & $\mathrm{x}$ & $\begin{array}{l}\text { Anti-constitutional agenda seeking to divide SA along racial lines incite racial } \\
\text { disparity }\end{array}$ \\
\hline 90 & Briliant: johan battersby unpacks nenegate, jacob zuma's greatest blunder & $\mathrm{x}$ & $\begin{array}{l}\text { Nene obervance of procurement procedures leads to growing band of zuma } \\
\text { critics }\end{array}$ \\
\hline 91 & $\begin{array}{l}\text { Robert Miller: good ship rsa leaking badly: those in cheap seats don't } \\
\text { know }\end{array}$ & $\mathrm{x}$ & $\begin{array}{l}\text { Satirical piece - mismanaging, neglecting repairs, untrained crew on critical } \\
\text { systems }\end{array}$ \\
\hline 92 & Mailbox: zuma's \#nenegate insanity. 10 reasons you should be worried & $\mathrm{x}$ & $\begin{array}{l}\text { Food, travel, inflation, market, borrow, unemployment, crime, emigration, taxes, } \\
\text { debt }\end{array}$ \\
\hline \multirow[t]{2}{*}{93} & Destructive zuma busy hollowing out the beloved country & $\mathrm{x}$ & $\begin{array}{l}\text { Zuma's misrule has gone mainstream - government procurement riddled with } \\
\text { graft }\end{array}$ \\
\hline & & 2016 & \\
\hline 94 & Black entrepreneur, editors defend chris hart & 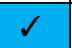 & Economics voices - punish ignorant views - transformation equates to mediocrity \\
\hline 95 & Twittercide: chris hart - is this the track record of a racist? & $\mathrm{X}$ & Economist widely condemned as racist - he isn't - causes racial polarization \\
\hline 96 & We are working to strengthen state-owned enterprises - zuma & $\mathrm{x}$ & Achievement of financial sustainability through office chief procurement officer \\
\hline 97 & Redistribution is a moral imperative - zuma & 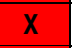 & Manage public funds responsibly - a choice between growth and redistribution \\
\hline 98 & Do away with policies based on race - mashaba & $x$ & Do away with policies based on race including black economic empowerment \\
\hline 99 & Anc using race to loot the country - mashaba & $\mathrm{x}$ & $\begin{array}{l}\text { Race-based politics - use race to divide - anc ploicies only benefit them and } \\
\text { cronies }\end{array}$ \\
\hline 100 & Witch hunt and selective condemnation & $\mathbf{X}$ & Outrage over racism cover-up by - calls for racial extermination \\
\hline 101 & Zuma needs to be honest & $x$ & Zuma \& anc let nation down - corruption, cadre deployment, mismanagement \\
\hline 102 & Pic funding claims 'intended to tarnish its integrity' & $\mathrm{x}$ & $\begin{array}{l}\text { Public investment corporation transferred r } 40 \mathrm{~m} \text { into account to pay anc staff - } \\
\text { claim }\end{array}$ \\
\hline 103 & Maimane got racism reduced & $x$ & $\begin{array}{l}\text { America own form of BEE and ee laws - yet system hard to crack - refuse } \\
\text { watering down }\end{array}$ \\
\hline 104 & Anc wants kohler to pay r 500000 , face criminal charges & $x$ & Anc taking racist to court - kumalo called to do to whites what hitler did to jews \\
\hline 105 & The "racist" shield: free speech on trail & $\mathrm{X}$ & White resentment through process of systemic racial exclusion \\
\hline 106 & SA moves five places on corruption perception index & $\checkmark$ & Extent of corruption in the country stabilising \\
\hline 107 & SA walking ratings tightrope & $\mathrm{X}$ & $\begin{array}{l}\text { Standard \& Poor - lower sa's rating - electricity shortage, weak business } \\
\text { confidence }\end{array}$ \\
\hline 108 & Is gordhan sa's knight is shining armour? & $\mathrm{x}$ & $\begin{array}{l}\text { Assurances to the world - SA wakes up to the real mess by nenegate - } \\
\text { pragmatism }\end{array}$ \\
\hline 109 & Racism can't be cured or debated - mantashe & $\mathbf{x}$ & Transform the economy and access to land - address inequality and racism \\
\hline 110 & Racism can't be cured or debated & $\mathbf{X}$ & Counter argument - state to protect human rights violation caused by corruption \\
\hline
\end{tabular}

Proposition 1: decision criteria - majority blue impact: accept proposition BEE directly or indirectly has a positive influence on the economic growth social development and political democracy of South Africa.

Table 1B (references). Impact of BEE (January 2015-January 2016)

\begin{tabular}{|c|c|c|c|c|}
\hline № & Date & Source & Author & Reference \\
\hline 67 & 16.02 .2015 & FIN24 & Jan de Lange & http://fin24.com/Companies/Mining/Anglo-could-pull-plug-on-Eskom-coal-supply-20150216 \\
\hline 68 & 13.05 .2015 & FIN24 & Donwald Pressly & http://www.fin24.com/Economy/Economy-is-not-working-Patel-told-20150513 \\
\hline 69 & 16.05 .2015 & M.NEWS24 & & http://m.news24.com/fin24/Economy/sa-bee-criticism-casts-dark-cloud-on-mining-20150516 \\
\hline 70 & 22.05 .2015 & FIN24 & & http://www.fin24.com/Companies/Industrial/Flaccid-dti-lacks-courage-20150522 \\
\hline 71 & 01.06 .2015 & NEWS24 & Sacha Coquelin & http://www.news24.com/MyNews24/Farewell-Rainbow-Nation-20150601 \\
\hline 72 & 17.06 .2015 & M\&G & Adam Wakefield & http://mg.co.za/article/2015-06-17-government-in-denial-about-corruption-alliance/ \\
\hline 73 & 29.06 .2015 & FIN24 & & http://www.fin24.com/Entrepreneurs/News/Business-must-step-up-to-plate-as-dti-dithers-on-BEE-20150629 \\
\hline 74 & 29.06 .2015 & FIN24 & & http://www.fin24.com/Economy/The-true-value-of-SAs-BEE-deals-revealed-20150629 \\
\hline 75 & 09.07.2015 & FIN24 & Anthea Jeffery & $\begin{array}{l}\text { http://www.fin24.com/BizNews/Time-to-halt-BEE-replace-with-economic-empowerment-for-the-disadvantaged- } \\
20150708\end{array}$ \\
\hline 76 & 21.07.2015 & NEWS24 & $\begin{array}{l}\text { MARTIN } \\
\text { WARBURG }\end{array}$ & $\begin{array}{l}\text { http://voices.news24.com/martin-warburg/2015/07/transformation-unintended-consequences-felonies-subvert- } \\
\text { democracy/ }\end{array}$ \\
\hline 77 & 21.08 .2015 & FIN24 & & http://www.fin24.com/Economy/Key-interventions-did-not-shift-economy-ANC-20150821 \\
\hline 78 & 25.08 .2015 & NEWS24 & Thomas Hartleb & http://www.news24/SouthAfrica/Politics/Corruption-a-cancer-to-development-ANC-20150825 \\
\hline 79 & 27.08.2015 & FIN24 & & $\begin{array}{l}\text { http://www.fin24.com/BizNews/Manyi-White-Owned-business-has-betrayed-Mandelas-reconciliation-legacy- } \\
20150821\end{array}$ \\
\hline 80 & 27.08 .2015 & FIN24 & Leopold Scholtz & http://www.fin24.com/Opinion/SA-Inc-only-as-strong-as-its-leadership-20150827 \\
\hline 81 & 11.09.2015 & FIN24 & Dane Mcdonald & http://www.fin24.com/Economy/Eskom/Vavi-Corruption-at-root-of-Eskom-load-shedding-20150911 \\
\hline 82 & 18.09.2015 & FIN24 & & http://www.fin24.com/Economy/Phosa-slates-BEE-policy-20150918 \\
\hline 83 & 01.10 .2015 & NEWS24 & Martin Warburg & http://voices.news24.com/martin-warburg/2015/09/transformation-provocation-confrontation-insurrection-looms/ \\
\hline
\end{tabular}


Table 1B (references) (cont.). Impact of BEE (January 2015-January 2016)

\begin{tabular}{|c|c|c|c|c|}
\hline № & Date & Source & Author & Reference \\
\hline 84 & 08.11 .2015 & NEWS24 & Ebrahim Harvey & http://wwww.news24.com/Opinions/Kgalema-Motlanthe-calling-it-as-it-is-20151108 \\
\hline 85 & 20.11 .2015 & FIN24 & Siseko Njobeni & http://www.fin24.com/Economis/mathews-posa-takes-swipe-at-jacob-zuma-20151120 \\
\hline 86 & 20.11 .2015 & FIN24 & Tim Knight & $\begin{array}{l}\text { http://www.fin24.com/BizNews/how-the-world-sees-us-tim-knight-sas-slide-from-madiba-to-zuma-oh-boy- } \\
20151120\end{array}$ \\
\hline 87 & 07.12 .2015 & NEWS24 & Amanda Khoza & http://www.news24.com/SouthAfrica/News/zulu-king-was-reflecting-on-apartheid-not-defending-it-20151207 \\
\hline 88 & 22.12.2015 & FIN24 & Trevor Manual & $\begin{array}{l}\text { http://www.fin24.com/BizNews/must-read-trevor-manuel-blasts-zumas-finmin-blunder-asks-tough-questions- } \\
20151222\end{array}$ \\
\hline 89 & 22.12.2015 & FIN24 & Herman Mashaba & $\begin{array}{l}\text { http://www.fin24.com/BizNews/herman-mashaba-responds-anc-failed-the-people-time-for-change- } \\
20151222\end{array}$ \\
\hline 90 & 24.12.2015 & FIN24 & John Batterby & $\begin{array}{l}\text { http://www.fin24.com/BizNews/brilliant-john-battersby-unpacks-nenegate-jacob-zumas-greatest-blunder- } \\
20151224\end{array}$ \\
\hline 91 & 28.12 .2015 & FIN24 & Robert Miller & $\begin{array}{l}\text { http://www.fin24.com/BizNews/robert-miller-good-ship-rsa-leaking-badly-those-in-cheap-seats-dont-know- } \\
20151228\end{array}$ \\
\hline 92 & 29.12.2015 & FIN24 & George Vine & $\begin{array}{l}\text { http://www.fin24.com/BizNews/mailbox-zumas-nenegate-insanity-10-reasons-you-should-be-worried- } \\
20151229\end{array}$ \\
\hline 93 & 30.12 .2015 & FIN24 & Alec Hogg & $\begin{array}{l}\text { http://www.fin24.com/BizNews/how-world-sees-sa-destructive-zuma-busy-hollowing-out-the-beloved- } \\
\text { country-20151230 }\end{array}$ \\
\hline \multicolumn{5}{|c|}{2016} \\
\hline 94 & 06.01 .2016 & FIN24 & M. le Cordeur & http://www.fin24.com/Tech/News/black-entrepreneur-editors-defend-chris-hart-20160106 \\
\hline 95 & 06.06 .2016 & FIN24 & ALEC HOGG & http://www.fin24.com/BizNews/twittercide-chris-hart-is-this-the-track-record-of-a-racist-20160106 \\
\hline 96 & 09.01 .2016 & NEWS24 & $\begin{array}{l}\text { K. Ngoepe \& } \\
\text { G. Quintal }\end{array}$ & $\begin{array}{l}\text { http://www.news24.com/SouthAfrica/News/we-are-working-to-strengthen-state-owned-enterprises-zuma- } \\
20160109\end{array}$ \\
\hline 97 & 09.01 .2016 & NEWS24 & $\begin{array}{l}\text { G. Quintal \& } \\
\text { K. Ngoepe }\end{array}$ & $\begin{array}{l}\text { http://www.news24.com/SouthAfrica/News/redistribution-is-a-moral-and-economic-imperative-zuma- } \\
20160109\end{array}$ \\
\hline 98 & 16.01 .2016 & NEWS24 & Genevieve Quintal & http://www.news24.com/SouthAfrica/News/do-away-with-policies-based-on-race-mashaba-20160116 \\
\hline 99 & 18.01 .2016 & NEWS24 & Genevieve Quintal & http://www.news24.com/SouthAfrica/News/anc-using-race-to-loot-the-country-mashaba-20160118 \\
\hline 100 & 19.01.2016 & NEWS24 & M. du Preex & http://www.news24.com/Columnists/MaxduPreez/witch-hunts-and-selective-condemnation-20160119 \\
\hline 101 & 20.01 .2016 & NEWS24 & Jenni Evans & http://www.news24.com/SouthAfrica/News/Zuma-needs-to-be-honest-buthelezi-20160120 \\
\hline 102 & 20.01 .2016 & NEWS24 & G. Quintal & http://www.news24.com/SouthAfrica/News/pic-funding-claims-intended-to-tarnish-its-integrity-20160120 \\
\hline 103 & 20.01 .2016 & NEWS24 & Bo Mbindwane & http://voices.news24.com/bo-mbindwane/2016/01/maimane-got-racism-bended/ \\
\hline 104 & 21.01.2016 & NEWS24 & T. Gqirana & $\begin{array}{l}\text { http://www.news24.com/SouthAfrica/News/anc-wants-kohler-barnard-to-pay-r500-000-face-criminal- } \\
\text { charges-20160121 }\end{array}$ \\
\hline 105 & 26.01 .2016 & NEWS24 & M. Warburg & http://voices.news24.com/martin-warburg/2016/01/racist-shield-free-speech-trial/ \\
\hline 106 & 27.01 .2016 & NEWS24 & G. Quintal & http://www.news24.com/SouthAfrica/News/sa-moves-five-places-on-corruption-perception-index-20160127 \\
\hline 107 & 27.01 .2016 & NEWS24 & C smith & http://www.fin24.com/Economy/sa-walking-ratings-tightrope-20160127 \\
\hline 108 & 27.01 .2016 & NEWS24 & S Moeng & http://www.fin24.com/Opinion/is-gordhan-sas-knight-in-shining-armour-20160127 \\
\hline 109 & 28.01 .2016 & NEWS24 & Genevieve Quintal & http://www.news24.com/SouthAfrica/News/racism-cant-be-cured-or-debated-mantashe-20160128 \\
\hline 110 & 29.01 .2016 & NEWS24 & A. Cordier & http://www.news24.com/MyNews24/racism-cant-be-cured-or-debated-mantashe-20160129-3 \\
\hline
\end{tabular}

Table 2. Movement towards socialism/communism of BEE (January 2014-January 2016)

\begin{tabular}{|l|l|c|l|}
\hline \multirow{2}{*}{ № Toitle } & & Year & \multirow{2}{*}{ Motivation } \\
\cline { 3 - 4 } & & 2014 & \\
\hline 1 & Socialism is a philosophy of failure & $\checkmark$ & Socialism relates closely to policies of the anc and certainly with those of eff \\
\hline 2 & Eff loud-mouth demagogues: cronin & $\checkmark$ & Sacp deputy accuses eff tenderpreneurs in red berets seeking self-enrichment \\
\hline 3 & Teach da a lesson : nzimande & $\checkmark$ & Sacp gs accuses da: black people are only good enough to march to parliament \\
\hline 4 & Grants helped keep anc in power - analyst & $\checkmark$ & Government social grants helped the anc to maintain its support \\
\hline 5 & Davies: SA at root of us, africa trade & X & SA is at the centre of exploring trade opportunities with the us - agoa \\
\hline 6 & SA is open to us investment - minister & X & International relations minister- SA needs more american companies to invest \\
\hline 7 & Zuma: south africa is open for business & X & Zuma explains how important us investment was \\
\hline 8 & Obama could have done more - zuma & X & Zuma's expectations in dealings with africa - believe they could have done more \\
\hline 9 & Radebe: minerals belong to the people as a whole & $\checkmark$ & Minerals belong to SA people as a whole and should embrace equity race and gender \\
\hline 10 & Sacp: eff a dangerous cancer & $\checkmark$ & Sacp says eff is dangerous cancer smashing parliament \\
\hline 11 & Putin-zuma growing closer: what for? & $\checkmark$ & Zuma and putin share opposition to imperialist tendencies of western powers \\
\hline 12 & The secret rise of communism in sa & $\checkmark$ & South africa is starting to look like a communist country \\
\hline 13 & State is auctioned to the highest bidder & $\checkmark$ & Freedom charter proclaims the people shall govern based on the will of the people \\
\hline 14 & The dalai lama and sa's visa dilemma & $\checkmark$ & SA worried about annoying china and thereby risking billions rands in investments \\
\hline 15 & Anc wants zuma shielded from 'humiliation' in parly & $\checkmark$ & Anc sg gwede mantashe believes the intended zuma humilation undermining democracy \\
\hline 16 & Parly should allow space to answer questions - mantashe & $\checkmark$ & Nec has noted how parliament has descended into chaos unruly offensive against anc \\
\hline
\end{tabular}


Table 2 (cont.). Movement towards socialism/communism of BEE (January 2014-January 2016)

\begin{tabular}{|c|c|c|c|}
\hline № & Title & Year & Motivation \\
\hline 17 & Opposition parties good for nothing - nzimande & 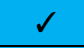 & Those who attack sacp will not survive - sacp proud to be associated with sadtu \\
\hline 18 & China 'does not dictate to sa' & $\checkmark$ & Perception of china dictates unfounded - is major trade partner \\
\hline 19 & Banks must serve people - nzimande & $\checkmark$ & Banks are exploitative and parasitic and use platform to change the economy \\
\hline 20 & Mantashe: mining sector suffers from trust deficit & $\checkmark$ & Government not night watchman for capital - ndp to achieve economic growth \\
\hline 21 & Nzimande: SA has plan for youth unemployment & $\mathrm{x}$ & "Marshall plan" to assist people unable to find decent employment \\
\hline 22 & Anc mps must use their numbers - mantashe & $\checkmark$ & Anc must use large numbers to take charge and make decisions \\
\hline 23 & Capital flight dwarfs corruption - sacp & $\checkmark$ & Problems of corruption dwarfed by capital flight and economic transformation \\
\hline 24 & Vosloo: anc wants to be big brother & $\checkmark$ & Independent press will find it harder to preserve media freedom under anc \\
\hline 25 & Numsa exit a case of self-expulsion - sacp & $\checkmark$ & Numsa leadership has no inclination to be constructive - sacp spokesperson \\
\hline 26 & Numsa expulsion: what it means for the anc & $\checkmark$ & Mantashe reaffirmed that numsa expulsion is bad for anc alliance \\
\hline 27 & South africa set to become a three party state & $\checkmark$ & Socialists, pragmatists, crony capitalists - socialism on the upsurge \\
\hline 28 & Regime change not a bad thing - prof & $\mathrm{X}$ & Replacement of anc would be good democracy in practice - sacp must be reminded \\
\hline 29 & Anc is the bodyguard of capitalism says eff & $\mathrm{X}$ & Anc government accused of being the bodyguard of white capital monopoly \\
\hline \multirow[t]{2}{*}{30} & Chinese imperialism and african elites are a toxic mixture & $\checkmark$ & China using africa as vast market to dump cheap goods and accommodate citizens \\
\hline & & 2015 & \\
\hline 31 & Govt won't let go of eskom, other soes - expert & $\checkmark$ & Government to "turn around" saa, sabc and sapo disasters on its own \\
\hline 32 & A show of who's boss & $\checkmark$ & Corrupt, inept movement, dominated by worshippers of lenin, stalin and the ussr \\
\hline 33 & Sa's democracy a juvenile delinquent & $\checkmark$ & Sacp hates eff being more socialist than sacp and using marxist rhetoric more often \\
\hline 34 & Floundering and needs to find its own fw de klerk & $\checkmark$ & SA heading for dictatorship - president doesn't regard himself as accountable \\
\hline 35 & SA violates international law once, twice, three times - analyst & $\checkmark$ & SA adopting a position on human rights which aligns with likes of china and russia \\
\hline 36 & Judiciary shouldn't interfere in politics - nzimade & $\checkmark$ & Sacp doctrine pushed that judiciary overreaching and interfering in political arena \\
\hline 37 & $\begin{array}{l}\text { Nzimande: al-bashir court challenge was attempt to embarrass } \\
\text { govt }\end{array}$ & $\checkmark$ & Sacp states protocols to be followed like un and au can't be less \\
\hline 38 & Al-bashir and the rule of law & $\checkmark$ & Zuma about-turn from the icc is watershed - damage to SA reputation immense \\
\hline 39 & $\begin{array}{l}\text { Anc actions point towards } 60 y \text { r old freedom charter - not the } \\
\text { constitution }\end{array}$ & $\checkmark$ & Freedom charter largely drawn up by communists approved by moscow \\
\hline 40 & I am white and i want to stay ... But & $\checkmark$ & The constitution and the disregard being dismantled in front of our very eyes \\
\hline 41 & Putin welcomes brics leaders amid standoff with west & $\checkmark$ & Moscow believes standoff with west over ukraine is isolated \\
\hline 42 & Eff: blade nzimande is an 'intellectual dwarf' & $\mathbf{X}$ & Sacp against eff who reject neoliberalism, embrace socialism and use marxism, leninism \\
\hline 43 & Trevor manuel's sacp critique important & $\mathrm{x}$ & Almost entire top structure of sacp in cabinet and $s g$ anc and president cosatu in sacp \\
\hline 44 & Anc wants to 'mend its ways' & $\checkmark$ & Eff gained $11 \%$ and da support grew by $6.5 \%$ - social transformation strong \\
\hline 45 & Icc showing SA 'cheeky arrogance' & $\checkmark$ & Western nations accused of using icc to effect regime change in africa \\
\hline 46 & Taxpayers fork out $r 7 \mathrm{~m}$ for 40 trips to china ... and counting & $\checkmark$ & China is destination of choice of government for officials and civil servants \\
\hline 47 & You had 20 years to focus economy on local industry & $\checkmark$ & Detestable capitalist economy where private sector not obliged to create employment \\
\hline 48 & Economic needs must trump anti-western ideology & $\checkmark$ & Anc intent on alienating the west by adopting pro-russia and china stance \\
\hline 49 & Socialist by name, capitalist by nature & $\checkmark$ & Is the anc still socialist? Sacp tail wagging the anc dog \\
\hline 50 & Equitable investment treaties? Protects china, chastises west & $\checkmark$ & China has bits SA agreement - why not eu and west? Dti terminates bits with eu states \\
\hline 51 & SA can't afford anti-west attacks & $\checkmark$ & Zuma goes out of his way to attack the west - "bite the hand that feeds you" \\
\hline 52 & Nzimande slams quality of journalism & $\checkmark$ & Sacp deplores media content as "horrifying" - media monopoly catered for middle class \\
\hline 53 & $\begin{array}{l}\text { Anc has abandoned its founding principles of the new South } \\
\text { Africa }\end{array}$ & $\checkmark$ & Anc has abandoned principles - resorts to bullying, propaganda and hostility \\
\hline 54 & Only cowards speak out against anc : zuma & $\checkmark$ & Anc shows signs of dictatorship - previous leaders are now biggest critics of the anc \\
\hline 54 & The anc comes first, not the country - zuma & $\checkmark$ & "the anc comes first" comment - people without revolutionary organisation in trouble \\
\hline 55 & Zuma's 'anc comes first' comments signs of a dictatorship & $\checkmark$ & Eff - anc speak language of dictators who think they hold monopoly of wisdom \\
\hline 56 & Zuma must apologise for 'anc comes first' comment - da & $\checkmark$ & Da - unbecoming of president's sworn oath to be faithful republic \\
\hline 57 & $\begin{array}{l}\text { Rich white men made mandela turn against the revolution - } \\
\text { malema }\end{array}$ & $\checkmark$ & Deviation of freedom charter beginning of selling out \\
\hline 58 & $\begin{array}{l}\text { 'Politicians who use mandela's name negatively are politically } \\
\text { bankrupt' }\end{array}$ & $\mathbf{x}$ & Anc critizes eff - being disingenuous and they will not engage such individuals \\
\hline 59 & Ramaphosa, dlamini hit out at malema & $\mathrm{X}$ & Ramaphosa rebukes eff leader - sacp more radical transformation \\
\hline 60 & $\begin{array}{l}\text { Africa, china relationship at its highest level ever following } \\
\text { summit - zuma }\end{array}$ & $\checkmark$ & Historic outcomes after summit with china who were there when help was needed \\
\hline 61 & 2016: eight risky events to watch in sa & $\checkmark$ & Barclays/absa disinvestment - government policy of economic nationalism \\
\hline 62 & Mandela didn't betray the people of sa & $\mathrm{X}$ & Anc leans towards more socialist approach \\
\hline
\end{tabular}


Table 2 (cont.). Movement towards socialism/communism of BEE (January 2014-January 2016)

\begin{tabular}{|c|l|c|l|}
\hline № & \multicolumn{1}{|c|}{ Title } & \multicolumn{1}{|c|}{ Year } & \multicolumn{1}{|c|}{ Motivation } \\
\hline & & 2016 & \\
\hline 63 & More China-SA 'in-depth' cooperation & $\mathrm{X}$ & More in depth coorperation - open up china economy - no-one in poverty \\
\hline 64 & Numsa still on track for new workers' party - jim & $\checkmark$ & Build marxist-leninist workers' party to replace capitalist with socialist society \\
\hline 65 & $\begin{array}{l}\text { Zuma panel no-show, gordhan rejected as SA stock falls even lower in } \\
\text { davos }\end{array}$ & $\checkmark$ & Zuma star attraction - no show most disappointing wef - difficult questions \\
\hline 66 & Would a black economy be the answer to racist white capital? & $\checkmark$ & $\begin{array}{l}\text { Black economy centered on employment - create community/state owned } \\
\text { companies }\end{array}$ \\
\hline
\end{tabular}

Table 2 (references). Movement towards socialism/communism of BEE (January 2014-January 2016)

\begin{tabular}{|c|c|c|c|c|}
\hline № & Date & Source & Author & Reference \\
\hline \multicolumn{5}{|c|}{2014} \\
\hline 1 & 24.04 .2014 & NEWS24 & Siphiwo Ntshuntshe & http://voices.news24.com/es-ntshuntshe/2014/04/socialism-philosophy-failure/ \\
\hline 2 & 01.05 .2014 & NEWS24 & & http://www.news24.com/Elections/News/EFF-loud-mouth-demagogues-Cronin-20140501 \\
\hline 3 & 01.05 .2014 & NEWS24 & & http://news24.com/Elections/News/Teach-DA-a-lesson-Nzimande-20140501 \\
\hline 4 & 09.05 .2015 & NEWS24 & & http://www.news24.com/Elections/News/Grants-helped-keep-ANC-in-power-analyst-20140509 \\
\hline 5 & 01.08 .2014 & FIN24 & & http://www.fin24.com/Economy/Davies-SA-at-root-of-US-Africa-trade-20140801 \\
\hline 6 & 04.08 .2014 & FIN24 & & http://www.fin24.com/Economy/SA-is-open-to-US-investment-minister-20140804 \\
\hline 7 & 05.08 .2014 & FIN24 & & http://www.fin24.com/Economy/Zuma-South-Africa-is-open-for-business-20140804 \\
\hline 8 & 05.08 .2014 & NEWS24 & & http://www.news24.com/SouthAfrica/News/Obama-could-have-done-more-Zuma-20140805 \\
\hline 9 & 14.08 .2014 & FIN24 & & http://www.fin24.com/Economy/Radebe-Minerals-belong-to-people-as-a-whole-20140814 \\
\hline 10 & 24.08 .2014 & NEWS24 & & http://www.news24.com/SouthAfrica/Politics/SACP-EFF-a-dangerous-cancer-20140824 \\
\hline 11 & 25.08 .2014 & NEWS24 & Siphamandla Zondi & http://voices.news24.com/siphamandla-zondi/2014/08/putin-zuma-growing-closer/ \\
\hline 12 & 02.09 .2014 & NEWS24 & Jp Le Roux & http://news24.com/MyNews24/The-secret-rise-of-communism-in-SA-20140902 \\
\hline 13 & 08.09.2014 & NEWS24 & Hubert Khobane & http://news24.com/MyNews24/State-is-auctioned-to-the-highest-bidder-20140908 \\
\hline 14 & 14.09.2014 & NEWS24 & Siphamandla Zondi & http://voices.news24.com/siphamandla-zondi/2014/09/dalai-lama-sas-visa-dilemma/ \\
\hline 15 & 20.09 .2014 & NEWS24 & & $\begin{array}{l}\text { http://www.news24.com/SouthAfrica/Politics/ANC-wants-Zuma-shielded-from-humiliation-in-Parly- } \\
20140920\end{array}$ \\
\hline 16 & 22.09 .2014 & NEWS24 & & $\begin{array}{l}\text { http://www.news24.com/SouthAfrica/Politics/Parly-should-allow-space-to-answer-questions-Mantashe- } \\
20140922\end{array}$ \\
\hline 17 & 02.20 .2014 & NEWS24 & & http://www.news24.com/SouthAfrica/Politics/Opposition-parties-good-for-nothing-Nzimande-20141002 \\
\hline 18 & 03.10 .2014 & NEWS24 & & http://www.news24.com/SouthAfrica/News/China-does-not-dictate-to-SA-20141003 \\
\hline 19 & 06.10 .2014 & FIN24 & & http://www.fin24.com/Money/Banking/Banks-must-serve-people-Nzimande-20141005-4 \\
\hline 20 & 09.10 .2014 & FIN24 & & http://www.fin24.com/Economy/Mantashe-Mining-sector-suffers-from-trust-deficit-20141008 \\
\hline 21 & 09.10 .2014 & FIN24 & & http://www.fin24.com/Economy/Nzimande-SA-has-plan-for-youth-unemployment-20141009 \\
\hline 22 & 12.10 .2014 & NEWS24 & & http://www.news24.com/SouthAfrica/Politics/ANC-MPs-must-use-their-numbers-Mantashe-20141012 \\
\hline 23 & 29.10 .2014 & FIN24 & & http://www.fin24.com/Economy/Capital-flight-dwarfs-corruption-SACP-20141029-3 \\
\hline 24 & 05.11 .2014 & NEWS24 & & http://www.news24.com/SouthAfrica/News/Vosloo-ANC-wants-control-of-Big-Brother-20141105 \\
\hline 25 & 11.11 .2014 & FIN24 & & http://www.fin24.com/Economy/Labour/News/Numsa-exit-a-case-of-self-expulsion-SACP-20141111 \\
\hline 26 & 11.11 .2014 & FIN24 & & http://www.fin24.com/Economy/Labour/News/Numsa-expulsion-What-it-means-for-the-ANC-20141111 \\
\hline 27 & 17.11.2014 & NEWS24 & & http://voices.news24.com/christo-van-der-rheede/2014/11/south-africa-set-become-three-party-state/ \\
\hline 28 & 04.12 .2014 & SAPA & & http://www.news24.com/SouthAfrica/Politics/Regime-change-not-a-bad-thing-prof-20141204 \\
\hline 29 & 15.12 .2014 & NEWS24 & & http://www.news24.com/SouthAfrica/News/ANC-is-the-bodyguard-of-capitalism-says-EFF-20141215 \\
\hline 30 & 22.12 .2014 & NEWS24 & Fairchance Ncube & http://voices.news24.com/fairchance-ncube/2014/12/chinese-imperialism-african-elites-toxic-mixture/ \\
\hline \multicolumn{5}{|c|}{2015} \\
\hline 31 & 09.02 .2015 & FIN24 & Daniel Silke & http://www.fin24.com/Economy/Govt-wont-let-go-of-Eskom-other-SOEs-expert-20150209 \\
\hline 32 & 19.02 .2015 & FIN24 & Leopold Scholtz & http://www.fin24.com/Economy/A-show-of-whos-boss-20150219 \\
\hline 33 & 24.02 .2015 & NEWS24 & Max du Preez & http://www.news24.com/Columnists/MaxduPreez/SAs-democracy-a-juvenile-delinquent-20150224 \\
\hline 34 & 25.02 .2015 & NEWS24 & Allister Sparks & $\begin{array}{l}\text { http://www.news24.com/Columnidts/AllisterSparks/Floundering-ANC-needs-to-find-its-own-FW-de- } \\
\text { Klerk-20150225 }\end{array}$ \\
\hline 35 & 17.06.2015 & NEWS24 & Janet Heard & $\begin{array}{l}\text { http://www.news24.com/SouthAfrica/News/SA-violates-international-law-once-twice-three-times- } \\
\text { analyst-20150616 }\end{array}$ \\
\hline 36 & 18.06.2015 & NEWS24 & Genevieve Quintal & http://www.news24.com/SouthAfrica/News/Judiciary-shouldnt-interfere-in-politics-Nzimande-20150618 \\
\hline 37 & 18.06.2015 & NEWS24 & Genevieve Quintal & $\begin{array}{l}\text { http://www.news24.com/SouthAfrica/News/Nzimande-Al-Bashir-court-challenge-was-attempt-to- } \\
\text { embarrass-govt-20150618 }\end{array}$ \\
\hline 38 & 25.06 .2015 & FIN24 & Leopold Scholtz & http://www.fin24.com/Economy/Al-Bashir-and-rule-of-law-20150625 \\
\hline 39 & 26.06 .2015 & BIZNEWS & Anthea Jeffery & $\begin{array}{l}\text { http://www.biznews.com/thought-leaders/2015/06/26/anthea-jeffrey-constitution-should-be-ancs-bible- } \\
\text { not-60-year-old-freedom-charter/ }\end{array}$ \\
\hline 40 & 07.07 .2015 & NEWS24 & Trevor Kleinhans & http://voices.news24.com/trevor-kleinhans/2015/07/i-am-white-and-i-want-to-stay-but/ \\
\hline 41 & 09.07 .2015 & FIN24 & & http://www.fin24.com/Economy/Putin-welcomes-Brics-leaders-amid-standoff-with-West-20150709 \\
\hline
\end{tabular}


Table 2 (references) (cont.). Movement towards socialism/communism of BEE (January 2014-January 2016)

\begin{tabular}{|c|c|c|c|c|}
\hline № & Date & Source & Author & Reference \\
\hline 42 & 13.07 .2015 & NEWS24 & Adam Wakefield & $\begin{array}{l}\text { http://www.news24.com/SouthAfrica/News/Politics/EFF-Blade-Nzimande-is-an-intellectual-dwarf- } \\
20150713\end{array}$ \\
\hline 43 & 14.07.2015 & NEWS24 & Max du Preez & $\begin{array}{l}\text { http://www.news24.com/Columinists/MaxduPreez/Trevor-Manuels-SACP-critique-important- } \\
20150714\end{array}$ \\
\hline 44 & 25.08 .2015 & NEWS24 & Genevieve Quintal & http://www.news24.com/SouthAfrica/Politics/ANC-wants-to-mend-its-ways-20150825 \\
\hline 45 & 25.08 .2015 & NEWS24 & Thomas Hartleb & http://www.news24.com/SouthAfrica/Politics/ICC-showing-SA-cheeky-arrogance-ANC-20150825 \\
\hline 46 & 31.08 .2015 & NEWS24 & Jan Gerber & $\begin{array}{l}\text { http://www.news24.com/SouthAfrica/News/Taxpayers-fork-out-R7m-for-40-trips-to-China-and- } \\
\text { counting-20150831 }\end{array}$ \\
\hline 47 & 02.09 .2015 & NEWS24 & Matome Letsoalo & $\begin{array}{l}\text { http://voices.news24.com/matome-letsoalo/2015/09/you-had-20-years-to-focus-economy-on- } \\
\text { local-industry/ }\end{array}$ \\
\hline 48 & 03.09 .2015 & NEWS24 & Anthea Jeffery & $\begin{array}{l}\text { http://www.fin24.com/BizNews/Anthea-Jeffery-Economic-needs-must-trump-anti-Western- } \\
\text { ideology-20150903 }\end{array}$ \\
\hline 49 & 17.09 .2015 & FIN24 & Leopold Scholtz & http://www.fin24.com/Opinion/Socialist-by-name-capitalist-by-nature-20150917 \\
\hline 50 & 23.09 .2015 & FIN24 & Anthea Jeffery & $\begin{array}{l}\text { http://www.fin24.com/Biznews/Anthea-Jeffery-Equitable-investment-treaties-Protects-China- } \\
\text { chastises-West-20150923 }\end{array}$ \\
\hline 51 & 01.10 .2015 & FIN24 & Leopold Scholtz & http://www.fin24.com/Opinion/SA-cant-afford-anti-West-attacks-20151001 \\
\hline 52 & 02.10 .2015 & NEWS24 & Jeanette Chabalala & http://www.news24.com/SouthAfrica/News/Nzimande-slams-quality-of-journalism-20151002 \\
\hline 53 & 09.10 .2015 & NEWS24 & Wilmot James & $\begin{array}{l}\text { http://www.news24.com/SouthAfrica/News/ANC-has-abandoned-its-founding-principles-of-the- } \\
\text { new-South-Africa-Wilmot-James-20151009 }\end{array}$ \\
\hline 54 & 07.11 .2015 & NEWS24 & A. Khoza \& G. Quintal & http://www.news24.com/SouthAfrica/News/zuma-says-hes-not-a-liability-20151107 \\
\hline 54 & 08.11 .2015 & NEWS24 & Genevieve Quintal & http://www.news24.com/SouthAfrica/News/the-anc-comes-first-not-the-country-zuma-20151108 \\
\hline 55 & 08.11 .2015 & NEWS24 & Genevieve Quintal & $\begin{array}{l}\text { http://www.news24.com/SouthAfrica/News/zumas-anc-comes-first-comments-signs-of-a- } \\
\text { dictatorship-eff-20151108 }\end{array}$ \\
\hline 56 & 08.11 .2015 & NEWS24 & Genevieve Quintal & $\begin{array}{l}\text { http://www.news24.com/SouthAfrica/News/zuma-must-apologise-for-anc-comes-first-comment- } \\
\text { da-20151108 }\end{array}$ \\
\hline 57 & 26.11 .2015 & NEWS24 & Ahmed Areff & $\begin{array}{l}\text { http://www.news24.com/SouthAfrica/News/rich-white-men-made-mandela-turn-against-the- } \\
\text { revolution-malema-20151126 }\end{array}$ \\
\hline 58 & 28.11.2015 & NEWS24 & Genevieve Quintal & $\begin{array}{l}\text { http://www.news24.com/SouthAfrica/News/politicians-who-use-mandelas-name-negatively-are- } \\
\text { politically-bankrupt-20151128 }\end{array}$ \\
\hline 59 & 05.12 .2015 & NEWS24 & Jeff Wicks & http://www.news24.com/SouthAfrica/News/ramaphosa-dlamini-hit-out-at-malema-20151205 \\
\hline 60 & 05.12 .2015 & NEWS24 & Thulani Gqirana & $\begin{array}{l}\text { http://www.news24.com/SouthAfrica/News/africa-china-relationship-at-its-highest-level-ever- } \\
\text { following-summit-zuma-20151205 }\end{array}$ \\
\hline 61 & 28.12 .2015 & FIN24 & & http://www.fin24.com/Economy/2016-eight-risky-events-to-watch-in-sa-20151228 \\
\hline 62 & 29.12.2015 & NEWS24 & Max du Preez & $\begin{array}{l}\text { http://www.news24.com/Columnists/MaxduPreez/mandela-didnt-betray-the-people-of-sa- } \\
20151229\end{array}$ \\
\hline \multicolumn{5}{|c|}{2016} \\
\hline 63 & 19.01.2016 & FIN24 & C. Smith & http://www.fin24.com/Economy/more-china-sa-in-depth-cooperation-ahead-20160119 \\
\hline 64 & 20.01 .2016 & FIN24 & S. Njobeni & $\begin{array}{l}\text { http://www.fin24.com/Economy/Labour/News/numsa-still-on-track-for-new-workers-party-jim- } \\
20160120\end{array}$ \\
\hline 65 & 21.01 .2016 & FIN24 & A. Hogg & $\begin{array}{l}\text { http://www.fin24.com/Biznews/zuma-panel-no-show-gordhan-rejected-as-sa-stock-falls-ever- } \\
\text { lower-in-davos-20160121 }\end{array}$ \\
\hline 66 & 21.01.2016 & NEWS24 & M. Letsoalo & $\begin{array}{l}\text { http://voices.news24.com/matome-letsoalo/2016/01/could-a-black-economy-be-the-answer-to- } \\
\text { racist-white-capital/ }\end{array}$ \\
\hline
\end{tabular}

Proposition 2: decision criteria - majority blue movement - accept proposition BEE moves SA away from western capitalism to socialism and communism. 